\title{
The effect of the Mo/W ratio on the catalytic properties of alumina supported hydrotreating catalysts prepared from mixed $\mathrm{SiMo}_{6} \mathrm{~W}_{6}$ and $\mathrm{SiMo}_{9} \mathrm{~W}_{3}$ heteropolyacids
}

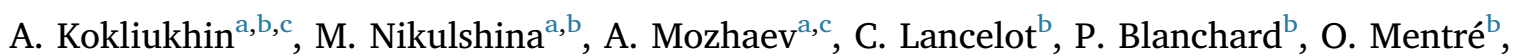 \\ M. Marinova ${ }^{\mathrm{e}}$, C. Lamonier ${ }^{\mathrm{b}, * *}$, P. Nikulshin ${ }^{\mathrm{a}, \mathrm{c}, \mathrm{d}, *}$ \\ ${ }^{a}$ Samara State Technical University, 244, Molodogvardeyskaya st., Samara, 443100, Russia \\ ${ }^{\mathrm{b}}$ Univ. Lille, CNRS, Centrale Lille, ENSCL, Univ. Artois, UMR 8181-UCCS - Unité de Catalyse et Chimie du Solide, F-59000, Lille, France \\ ${ }^{c}$ Gubkin Russian State University of Oil and Gas, Leninskiy Prospect 65, Moscow, 119991, Russia \\ ${ }^{\mathrm{d}}$ All-Russia Research Institute of Oil Refining, 6/1 Aviamotornaya st., Moscow, 111116, Russia \\ ${ }^{\mathrm{e}}$ Univ. Lille, CNRS, INRA, Centrale Lille, ENSCL, Univ. Artois, FR 2638 - IMEC - Institut Michel-Eugène Chevreul, F-59000, Lille, France
}

\section{A R T I C L E I N F O}

\section{Keywords:}

Hydrodesulfurization

Hydrogenation

$\mathrm{SiMo}_{\mathrm{n}} \mathrm{W}_{12-\mathrm{n}} \mathrm{HPA}$

MoW mixed phase

DBT

\begin{abstract}
A B S T R A C T
New mixed $\mathrm{H}_{4}\left[\mathrm{SiMo}_{\mathrm{n}} \mathrm{W}_{\mathrm{n}-12} \mathrm{O}_{40}\right]$ ( $\mathrm{n}=6$ and 9) Keggin type heteropolyacids (HPAs) have been successfully synthesized, as confirmed by single-crystal XRD, Raman and IR spectroscopy analysis. The resulting polyoxometallates were used for preparation of hydrotreatment catalysts. $\mathrm{Mo}(\mathrm{W}) / \mathrm{Al}_{2} \mathrm{O}_{3}$ catalysts were synthesized by incipient wetness impregnation of alumina support with water solutions of prepared mixed Keggin HPAs and corresponding counterparts based on mixture of monometallic $\mathrm{H}_{4}\left[\mathrm{SiMo}_{12} \mathrm{O}_{40}\right]$ and $\mathrm{H}_{4}\left[\mathrm{SiW}_{12} \mathrm{O}_{40}\right]$ HPAs. Oxidic catalysts were analyzed by Raman spectroscopy to determine the precursor structure after deposition. Catalysts in sulfided state were characterized by high-resolution transmission electron microscopy (HRTEM), high angle annular dark field imaging (HAADF) and X-ray photoelectron spectroscopy (XPS) and were tested in co-hydrotreating of dibenzothiophene (DBT) and naphthalene. The use of new mixed Keggin HPAs made it possible to obtain catalysts with mixed MoWS $_{2}$ active centers, which was confirmed by HAADF. Moreover, the Mo/(Mo + $\mathrm{W})$ ratio has a direct effect on the structure of the active phase species. An ordered core-shell structure with Mo atoms in the core is maintained until the fraction of molybdenum in mixed $\mathrm{MoW} / \mathrm{Al}_{2} \mathrm{O}_{3}$ catalyst exceeds $50 \%$, where a more disordered structure is observed. Moreover, this $\mathrm{Mo} /(\mathrm{Mo}+\mathrm{W})$ ratio of 0.5 is optimal to achieve a maximum catalytic activity. Indeed, the turnover frequencies (TOF) of the $\mathrm{MoWS}_{2}$ edge centers with random atoms distribution in a cluster as in $\mathrm{Mo}_{9} \mathrm{~W}_{3} / \mathrm{Al}_{2} \mathrm{O}_{3}$, was lower compared to that of $\mathrm{Mo}_{6} \mathrm{~W}_{6} / \mathrm{Al}_{2} \mathrm{O}_{3}$ with core-shell structure.
\end{abstract}

\section{Introduction}

The main problem of oil refining is the quality of the produced fuel, especially diesel and gasoline, as the world demand for these types of fuel increases every year, while environmental standards for diesel fuel have noticeably tightened [1,2]. According to the U.S. Energy Information Administration for 2018, global liquid fuels demand will increase more than $20 \%$ in 2050 [3], and the demand for motor fuels will reach 107 million barrels per day [4]. At the same time, the availability of light oil is ending and therefore the world has recently been paying more and more attention to the use of heavy viscous oil sources, implying the use of more severe conditions in the technology of hydrodesulfurization (HDS) (e.g., high temperature, high pressure, and high hydrogen consumption), which result in higher operating cost [5]. In this regard, the development of new catalytic systems for hydrogenation processes in order to produce ultra-pure motor fuels continues.

Increasingly, the attention of researchers is focused on the use of mixed Mo-W systems, promoted by $\mathrm{Co}$ or $\mathrm{Ni}$, to create new highly active hydrotreating catalysts [6-12]. Raybaud and co-workers [6] have calculated that NiMoWS 2 phases are more active than NiMoS and NiWS ones, thanks to the optimal binding energy between sulfur and metal. Moreover, Hensen and co-workers [8] considered that depending on the sulfiding conditions two models of $\mathrm{MoWS}_{2}$ mixed active phase can be

\footnotetext{
* Corresponding author at: Samara State Technical University, 244 Molodogvardiyskaya st., Samara city, 443100, Russia.

*** Corresponding author.

E-mail addresses: carole.lamonier@univ-lille.fr (C. Lamonier), p.a.nikulshin@gmail.com (P. Nikulshin).
} 
Table 1

. Crystal data, data collection and structure refinement parameters for $\mathrm{H}_{4}\left[\mathrm{SiMo}_{6} \mathrm{~W}_{6} \mathrm{O}_{40}\right] \cdot 36 \mathrm{H}_{2} \mathrm{O}$ and $\mathrm{H}_{4}\left[\mathrm{SiMo}_{9} \mathrm{~W}_{3} \mathrm{O}_{40}\right] 36 \mathrm{H}_{2} \mathrm{O}$.

\begin{tabular}{|c|c|c|}
\hline \multicolumn{3}{|l|}{ Crystal data } \\
\hline Cluster formula & $\mathrm{H}_{4}\left[\mathrm{SiMo}_{6} \mathrm{~W}_{6} \mathrm{O}_{40}\right]$ & $\mathrm{H}_{4}\left[\mathrm{SiMo}_{9} \mathrm{~W}_{3} \mathrm{O}_{40}\right]$ \\
\hline Crystal symmetry & Tetragonal & \\
\hline Space group & $\mathrm{P}-42_{1} \mathrm{c}$ & \\
\hline Working temp. (K) & 100 & 293 \\
\hline Unit cell (Å) & $\mathrm{a}=12.732(2)$ & $12.7447(3)$ \\
\hline & $=18.0525(6)$ & $8.0632(9)$ \\
\hline Volume $\left(\AA^{3}\right)$ & 2926.38 & 2933.96 \\
\hline $\mathrm{Z}, \mathrm{Mw}$ & $2,2994.8$ & 2, 2761.02 \\
\hline Calculated density $\left(\mathrm{g} / \mathrm{cm}^{3}\right)$ & 3.40 & 3.12 \\
\hline \multicolumn{3}{|l|}{ Data collection } \\
\hline Equipment & Bruker Apex Duo & \\
\hline Radiation MoKa $(\AA)$ & 0.71073 & \\
\hline Scan mode & $\omega / \varphi$ - scan & \\
\hline Recorded angular range $\theta\left({ }^{\circ}\right)$ & $1.96-33.13$ & $1.96-31.69$ \\
\hline Recording reciprocal space & $-15 \leq h \leq 19$ & $-18 \leq h \leq 18$ \\
\hline & $-19 \leq \mathrm{k} \leq 16$ & $-18 \leq \mathrm{k} \leq 18$ \\
\hline & $-27 \leq 1 \leq 27$ & $-26 \leq 1 \leq 26$ \\
\hline N. ind. Ref. & 2656 & 2672 \\
\hline N. ind. Ref. $[\mathrm{I}>3 \sigma(\mathrm{I})]$ & 2465 & 2222 \\
\hline$\mu\left(\mathrm{cm}^{-1}\right)(\lambda=\mathrm{MoK} \alpha)$ & 131.1 & 78.8 \\
\hline Absorption correction & analytical (Sadabs) & \\
\hline R merging factor (\%) & 4.12 & 4.22 \\
\hline \multicolumn{3}{|l|}{ Refinement parameters } \\
\hline Software & Jana 2000 & \\
\hline Number of refined parameters & 106 & 107 \\
\hline $\mathrm{R}_{1}(\mathrm{~F})$ all, $[\mathrm{I}>3 \sigma(\mathrm{I})]=\sum|| F_{O}|-| F_{C}|| / \sum\left|F_{O}\right|(\%)$ & $3.62,4.01$ & $3.45,4.67$ \\
\hline $\mathrm{wR}_{2}\left(\mathrm{~F}^{2}\right)$ all, $[\mathrm{I}>3 \sigma(\mathrm{I})]=\left[\sum w\left(F_{O}^{2}-F_{C}^{2}\right)^{2} / \sum w\left(F_{O}^{2}\right)\right]^{1 / 2}(\%)$ & $3.85,4.14$ & $.27,5.21$ \\
\hline Weight & unit & $1 /\left(\sigma^{2^{\wedge}}(\mathrm{F})+0.0001 \mathrm{~F}^{2}\right)$ \\
\hline Isotropic secondary extinction & none & none \\
\hline $\operatorname{Max} / \operatorname{Min} \Delta \rho$ e $/ \AA^{3}$ & $-1.37 / 1.95$ & $-1.05 / 1.81$ \\
\hline
\end{tabular}

formed: with random distribution of Mo and $\mathrm{W}$ atoms and a core-shell structure, where Mo is mainly located in the core, and $\mathrm{W}$ in the shell. It was found that $\mathrm{NiMo}_{0.75} \mathrm{~W}_{0.25} / \mathrm{Al}_{2} \mathrm{O}_{3}$ catalyst with a random distribution of Mo and W atoms in mixed MoWS 2 slabs was formed in liquid phase sulfidation conditions and was more active in the gas oil hydrotreatment compared to $\mathrm{NiMo} / \mathrm{Al}_{2} \mathrm{O}_{3}$. Mixed $\mathrm{MoWS}_{2}$ slabs with a core-shell structure were formed in gas sulfidation conditions and their testing in thiophene HDS did not show any synergistic effect.

Various types of mixed MoW systems can be found in the literature, which preparation mostly involves traditional precursors of the active phase, such as ammonium heptamolybdate (AHM), ammonium paratungstate (APT), ammonium metatungstate (AMT) and ammonium tungstate. [10-12]. Heteropolycompounds, such as Keggin and Kegginderivated heteropolymolybdate and heteropolytungstate structures, can be used as starting oxidic precursor for highly active hydrotreating catalysts [13-17]. We have previously proposed a new method to synthetize (Ni)MoW catalysts using mixed $\mathrm{H}_{4}\left[\mathrm{SiMo}_{1} \mathrm{~W}_{11} \mathrm{O}_{40}\right]$ and $\mathrm{H}_{4}\left[\mathrm{SiMo}_{3} \mathrm{~W}_{9} \mathrm{O}_{40}\right]$ heteropolyacids (HPA), allowing to introduce both Mo and $W$ metals in a catalyst from a single molecular precursor [18]. It was found that such catalysts are more efficient than their counterparts obtained from a mixture of monometallic HPAs with the same Mo/(Mo $+\mathrm{W})$ ratio, which was related to the formation of a mixed $\mathrm{MoWS}_{2}$ phase when using mixed HPA as precursor [19,20]. Moreover, it was found that when increasing the $\mathrm{Mo} /(\mathrm{Mo}+\mathrm{W})$ atomic ratio from 0.08 to 0.25 , the catalytic activity also increases. However, a synthesis methodology has only been published for HPAs with Mo/W molar ratio equal to $1 / 11$ and $3 / 9$ [19]. In this work, we have successfully synthesized new Keggin HPAs with a Mo/W molar ratio equal to 6/6 and $9 / 3$, which were characterized by XRD, Raman and IR spectroscopy. The purpose of this study was to determine the effect of the increase of the $\mathrm{Mo} /(\mathrm{Mo}+\mathrm{W})$ molar ratio on the formation of the mixed $\mathrm{MoWS}_{2}$ active phase and subsequently on the catalytic activity in dibenzothiophene (DBT) HDS and naphthalene hydrogenation (HYD).
The performance in the hydrotreating reactions of DBT and naphthalene was evaluated and compared to that of reference catalysts obtained from a mixture of two monometallic Mo and $\mathrm{W}$ based HPAs with the same $\mathrm{Mo} /(\mathrm{Mo}+\mathrm{W})$ ratio. All catalysts were activated under gas phase sulfidation under a flow of $\mathrm{H}_{2} \mathrm{~S} / \mathrm{H}_{2}(10$ vol. \%) and characterized by XPS, HRTEM and HAADF.

\section{Experimental}

2.1. Synthesis of mixed $\mathrm{H}_{4}\left[\mathrm{SiMo}_{n} W_{12-n} \mathrm{O}_{40}\right]$ heteropolyacids (HPAs) ( $n$ $=1,3,6,9$ )

Mixed $\alpha-\mathrm{H}_{4}\left[\mathrm{SiMo}_{1} \mathrm{~W}_{11} \mathrm{O}_{40}\right]$ and $\beta-\mathrm{H}_{4}\left[\mathrm{SiMo}_{3} \mathrm{~W}_{9} \mathrm{O}_{40}\right]$ heteropolyacids (hereafter $\mathrm{SiMo}_{1} \mathrm{~W}_{11}$ and $\mathrm{SiMo}_{3} \mathrm{~W}_{9}$ ) have been synthesized from their corresponding mixed potassium salt starting from mono(tri)-vacant heteropolytungstates according to previous reports [19].

Two new $\mathrm{SiMo}_{\mathrm{n}} \mathrm{W}_{12-\mathrm{n}}$ HPAs with Mo/W molar ratio equal to $6 / 6$ and 9/3 were synthesized by a new method using monometallic $\mathrm{H}_{4}\left[\mathrm{SiMo}_{12} \mathrm{O}_{40}\right]\left(\mathrm{SiMo}_{12}\right)$ and $\mathrm{H}_{4}\left[\mathrm{SiW}_{12} \mathrm{O}_{40}\right]\left(\mathrm{SiW}_{12}\right)$ HPAs as starting materials:

- for $\mathrm{Mo} / \mathrm{W}=6 / 6: 4.12 \mathrm{~g}$ of $\mathrm{SiMo}_{12}$ and $6.21 \mathrm{~g}$ of $\mathrm{SiW}_{12}$ acids dissolved in $40 \mathrm{~mL}$ of distilled water;

- for $\mathrm{Mo} / \mathrm{W}=$ 9/3: $6.62 \mathrm{~g}$ of $\mathrm{SiMo}_{12}$ and $3.44 \mathrm{~g}$ of $\mathrm{SiW}_{12}$ acids dissolved in $48 \mathrm{~mL}$ of distilled water.

Yellow solutions were obtained in both cases. The acid solutions were heated to $80^{\circ} \mathrm{C}$ and kept for $1 \mathrm{~h}$. After that, potassium hydroxide was added to each solution in small portions until pH reaches 4. After the addition of alkali, the solution became slightly greenish. Both solutions were boiled for another $30 \mathrm{~min}$ at $80^{\circ} \mathrm{C}$ and then cooled to room temperature. It was noticed that the mixed corresponding acid was sufficiently stable to be crystallized from aqueous solution by using the "etherate" method [21]. The extraction and the crystallization were carried out according to the procedure described previously [19]. The 
Table 2

Composition and textural characteristics of sulfided $\mathrm{Mo}(\mathrm{W})$ catalysts.

\begin{tabular}{|c|c|c|c|c|c|c|}
\hline \multirow[t]{2}{*}{ Catalyst } & \multirow{2}{*}{$\begin{array}{l}\mathrm{d}(\mathrm{Me}) \text { at/ } \\
\mathrm{nm}^{2}\end{array}$} & \multicolumn{2}{|c|}{ Content (wt. \%) } & \multicolumn{3}{|c|}{ Textural characteristics } \\
\hline & & Mo & $\mathrm{W}$ & $\begin{array}{l}S_{\mathrm{BET}}^{\mathrm{a}} \\
\left.\mathrm{m}^{2} \mathrm{~g}^{-1}\right)\end{array}$ & $\begin{array}{l}V_{\mathrm{p}}^{\mathrm{b}} \\
\mathrm{cm}^{3} \\
\left.\mathrm{~g}^{-1}\right)\end{array}$ & $\begin{array}{l}D^{\mathrm{c}} \\
\mathrm{nm})\end{array}$ \\
\hline $\mathrm{Mo}_{12} / \mathrm{Al}_{2} \mathrm{O}_{3}{ }^{*}$ & 3.9 & 18.0 & - & 215 & 0.53 & 7.6 \\
\hline $\mathrm{Mo}_{9} \mathrm{~W}_{3} / \mathrm{Al}_{2} \mathrm{O}_{3}$ & & 13.1 & 7.1 & 204 & 0.56 & 7.7 \\
\hline $\mathrm{Mo}_{9}+\mathrm{W}_{3} / \mathrm{Al}_{2} \mathrm{O}_{3}$ & & & & 210 & 0.59 & 7.5 \\
\hline $\mathrm{Mo}_{6} \mathrm{~W}_{6} / \mathrm{Al}_{2} \mathrm{O}_{3}$ & & 8.5 & 13.8 & 191 & 0.58 & 7.9 \\
\hline $\mathrm{Mo}_{6}+\mathrm{W}_{6} / \mathrm{Al}_{2} \mathrm{O}_{3}$ & & & & 204 & 0.59 & 7.8 \\
\hline $\mathrm{Mo}_{3} \mathrm{~W}_{9} / \mathrm{Al}_{2} \mathrm{O}_{3} *$ & & 4.2 & 20.1 & 210 & 0.53 & 7.6 \\
\hline $\mathrm{Mo}_{3}+\mathrm{W}_{9} / \mathrm{Al}_{2} \mathrm{O}_{3}$ * & & & & 206 & 0.53 & 7.6 \\
\hline $\mathrm{W}_{12} / \mathrm{Al}_{2} \mathrm{O}_{3} *$ & & - & 26.2 & 208 & 0.54 & 7.6 \\
\hline
\end{tabular}

$S_{\mathrm{BET}}$ is the surface area, $V_{\mathrm{p}}$ is the pore volume, and $D$ is the pore diameter. * adapted from [20].

elemental composition and structures of the mixed heteropolyacids were confirmed by XRD, IR-, and Raman spectroscopy. The crystal data and the structure refinement parameters for the obtained crystals are given in Table 1.

\subsection{Preparation of the supported oxidic precursors}

The catalysts with surface density of the metals $d(\mathrm{Mo}+\mathrm{W})$ equal to 3.9 at $\mathrm{nm}^{-2}$ were prepared by incipient wetness impregnation of alumina support $\left[\gamma-\mathrm{Al}_{2} \mathrm{O}_{3}\right.$ (Norton), specific area: $240 \mathrm{~m}^{2} \mathrm{~g}^{-1}$, pore volume: $0.9 \mathrm{~mL} \mathrm{~g}^{-1}$ ] with the aforementioned impregnating solutions. The bimetallic $\mathrm{Mo}_{\mathrm{n}} \mathrm{W}_{12 \text {-n }}$ catalysts were prepared by using corresponding mixed $\mathrm{H}_{4}\left[\mathrm{SiMo}_{\mathrm{n}} \mathrm{W}_{\mathrm{n}-12} \mathrm{O}_{40}\right]$ HPAs and will be referred to as $\mathrm{Mo}_{\mathrm{n}} \mathrm{W}_{12-\mathrm{n}} / \mathrm{Al}_{2} \mathrm{O}_{3}$. Reference catalysts were also prepared using the impregnating solutions obtained by mixing $\mathrm{SiMo}_{12}$ and $\mathrm{SiMo}_{12}$ dissolved in aqueous solution with the same Mo/W ratio than that of the corresponding mixed HPAs and were denoted as $\mathrm{Mo}_{\mathrm{n}}+\mathrm{W}_{12-\mathrm{n}} / \mathrm{Al}_{2} \mathrm{O}_{3}$. The oxidic catalyst precursors after maturation were dried at $60{ }^{\circ} \mathrm{C}(4 \mathrm{~h})$ $80{ }^{\circ} \mathrm{C}(2 \mathrm{~h})$ and $100{ }^{\circ} \mathrm{C}(4 \mathrm{~h})$ in air atmosphere without further calcination. The chemical compositions of the prepared catalysts are given in Table 2. The oxidic catalysts were analyzed by Raman spectroscopy.

\subsection{Characterization of the solids}

\subsubsection{Raman and IR- spectroscopy}

The Raman spectra of the samples were recorded at RT using an Infinity XY Horiba Jobin-Yvon Raman microprobe equipped with a photodiode array detector. The excitation laser source was the 532.16

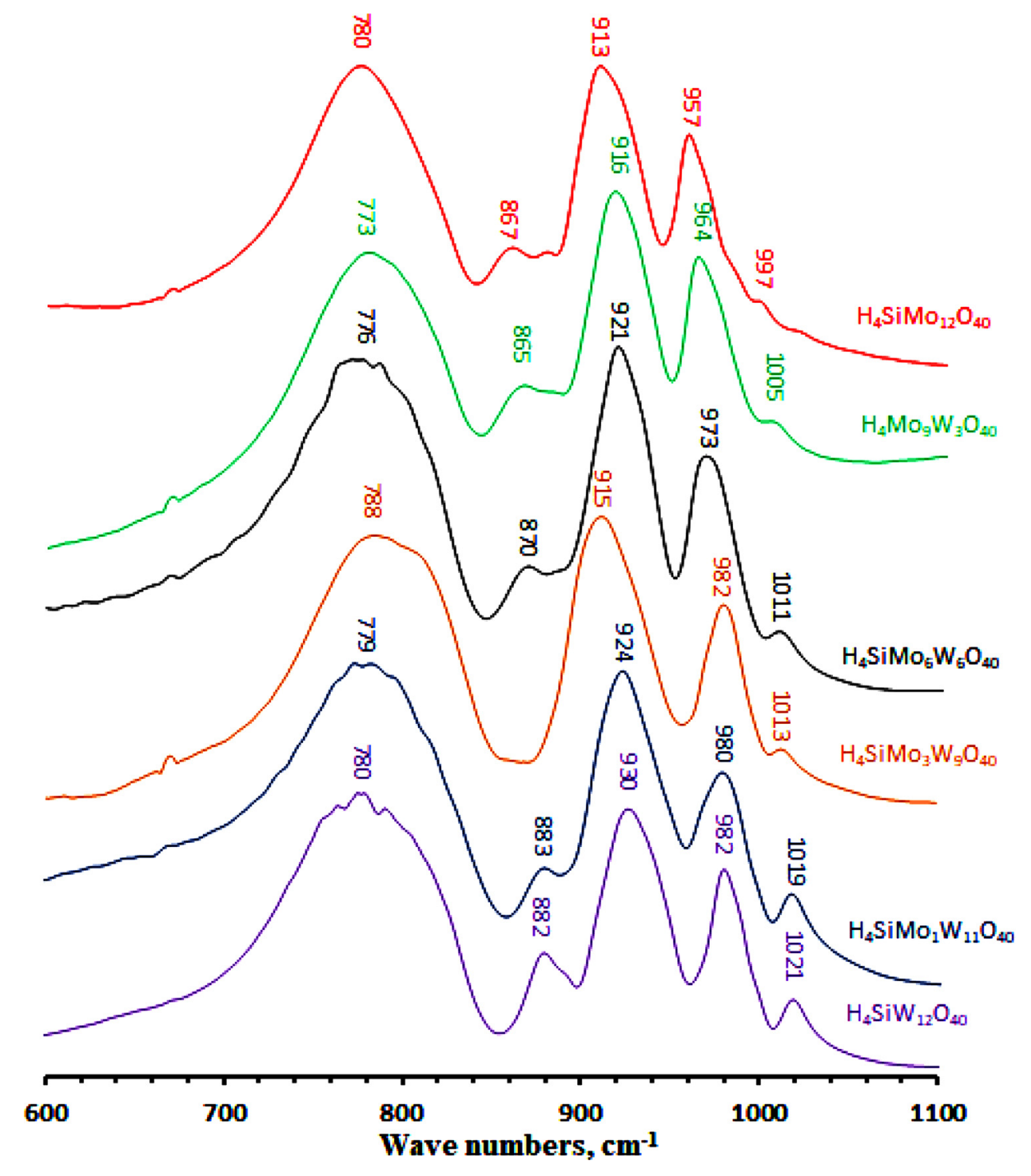

Fig. 1. IR-spectra for $\mathrm{SiMo}_{\mathrm{n}} \mathrm{W}_{12-\mathrm{n}} \mathrm{HPAs}$. 


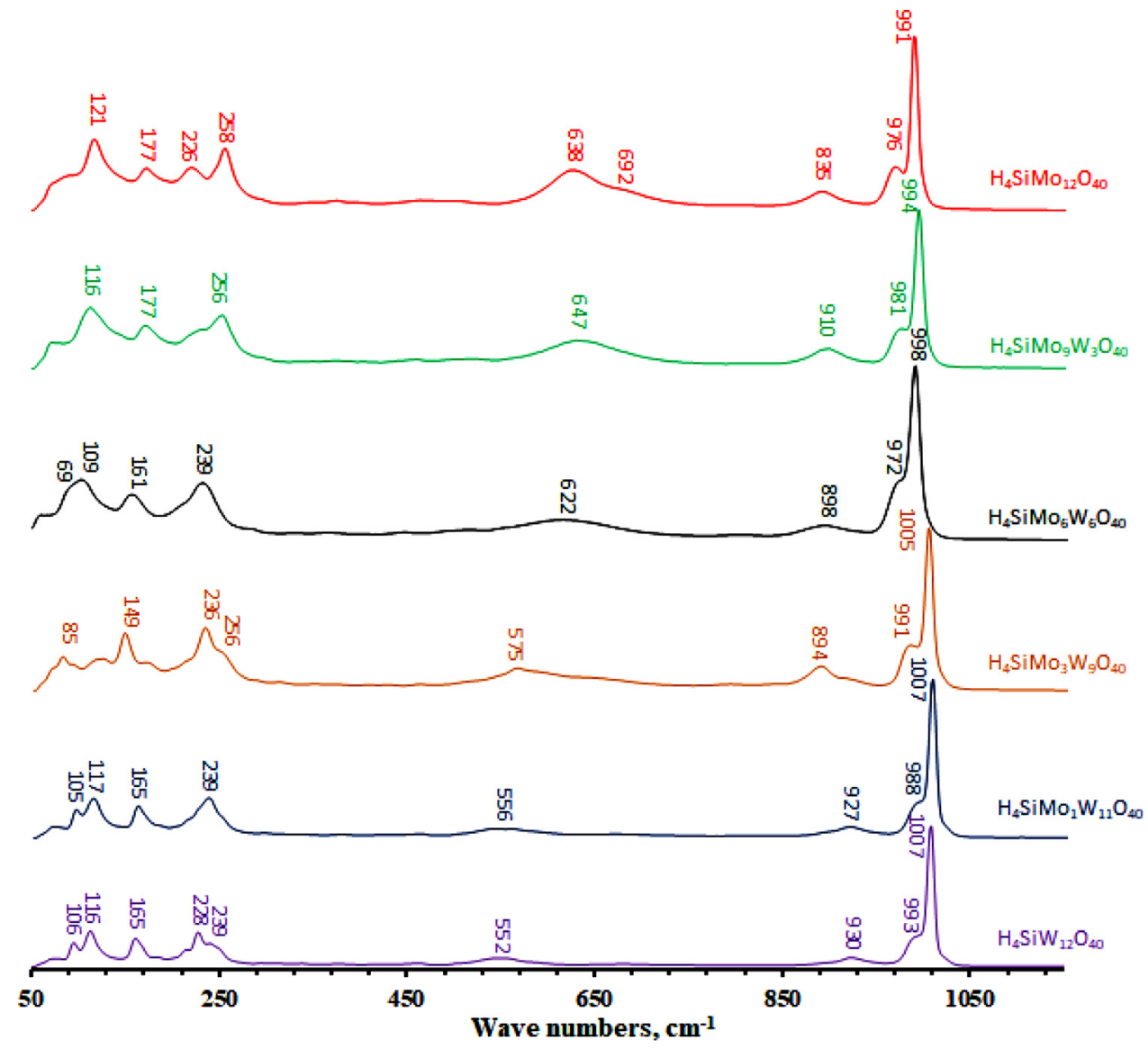

Fig. 2. Raman spectra for $\mathrm{SiMo}_{\mathrm{n}} \mathrm{W}_{12-\mathrm{n}} \mathrm{HPAs}$.

$\mathrm{nm}$ line of a Nd-YAG laser. The wavenumber accuracy was $4 \mathrm{~cm}^{-1}$. IR spectra of $\mathrm{H}_{4}\left[\mathrm{SiMo}_{\mathrm{n}} \mathrm{W}_{\mathrm{n}-12} \mathrm{O}_{40}\right]$ HPAs (as $\mathrm{KBr}$ pellets) $\left(400-4000 \mathrm{~cm}^{-1}\right.$ ) were measured on a Shimadzu IR Prestige-21 FT-IR spectrophotometer.

\subsubsection{Single-crystal $X$-ray diffraction $(X R D)$}

Single crystal XRD data for $\mathrm{H}_{4}\left[\mathrm{SiMo}_{6} \mathrm{~W}_{6} \mathrm{O}_{40}\right] \cdot 36 \mathrm{H}_{2} \mathrm{O}$ and $\mathrm{H}_{4}\left[\mathrm{SiMo}_{9} \mathrm{~W}_{3} \mathrm{O}_{40}\right] \cdot 36 \mathrm{H}_{2} \mathrm{O}$ have been collected using a Bruker Apex Duo diffractometer with a Mo-I $\mu$ S microfocus tube $(\lambda=0.71073 \AA)$. The intensity data have been extracted and corrected from Lorentz Polarization using the program SAINT-Plus 8.27b [22]. Multiscan absorption correction was applied using SADABS [23]. The structure was solved using Superflip [24] and refined using Jana 2006 [25]. Specificities for each collection and refinement are given in the crystal structure dedicated sections.

\subsection{Textural characteristics of the oxidic precursors}

The textural characteristics of the catalysts were measured on a Quantachrome Autosorb-1 adsorption porosimeter by low-temperature nitrogen adsorption at $77 \mathrm{~K}$. Before analysis, the samples were outgassed under vacuum $\left(<10^{-1} \mathrm{~Pa}\right)$ at $300{ }^{\circ} \mathrm{C}$ for $3 \mathrm{~h}$. The specific surface area (SSA) was calculated using the Brunauer-Emmett-Teller method at relative partial pressures $\left(\mathrm{P} / \mathrm{P}_{0}\right)$ ranging from 0.05 to 0.3 . Total pore volume (at $\mathrm{P} / \mathrm{P}_{0}$ of 0.99 ) and pore size distribution were obtained using the desorption curve and the Barret-Joyner-Halenda model.

\subsection{Characterization of the sulfided catalysts}

2.5.1. High resolution high-angle annular dark-field scanning transmission electron microscopy (HR HAADF-STEM)

HAADF-STEM analyses have been performed using a FEG TEM/ STEM system (Titan Themis FEI) operated at $300 \mathrm{kV}$, equipped with a monochromator and a probe Cs corrector. For HAADF acquisition, the spot size was 9 (probe size of the order of $500 \mathrm{pm}$ ) with a screen current of $\sim 50 \mathrm{pA}$ and collection angles for the HAADF detector of $\sim 50$ and $\sim 200$ mrad, respectively. The probe semi-convergence angle has been $21 \mathrm{mrad}$. All samples were ground under an inert atmosphere. In order to avoid contamination, the samples have been deposited in the form of dry powder, without solvents, on cupper grids with the lacey carbon film.

\subsubsection{High-resolution transmission electron microscopy (HRTEM)}

HRTEM was carried out using a Tecnai G2 20 electron microscope with $\mathrm{LaB}_{6}$ filament with a $0.19 \mathrm{~nm}$ lattice-fringe resolution and an accelerating voltage of $200 \mathrm{kV}$. The samples were dispersed in ethanol. The suspension was collected on carbon films supported on copper grids and 10-15 representative micrographs were obtained for each catalyst in high-resolution mode. Typically, the length and the stacking of at least 500 slabs were measured for each catalyst. ImageJ free software developed for direct qualitative analysis of images. The distribution in length and the stacking of the slabs was determined. To measure the extent of the $\mathrm{Mo}(\mathrm{W}) \mathrm{S}_{2}$ dispersion, the average fraction of $\mathrm{Mo}(\mathrm{W})$ atoms at the $\mathrm{Mo}(\mathrm{W}) \mathrm{S}_{2}$ edge surface $(D)$ was calculated, assuming that the Mo $(\mathrm{W}) \mathrm{S}_{2}$ slabs were perfect hexagons [26]. $\mathrm{Mo}(\mathrm{W}) \mathrm{S}_{2}$ dispersion $(D)$ was statistically evaluated by dividing the total number of $\mathrm{Mo}(\mathrm{W})$ atoms at the edge surface $\left(W_{\mathrm{e}}\right)$, including corner sites $\left(W_{\mathrm{c}}\right)$, by the total number of $\mathrm{Mo}(\mathrm{W})$ atoms $\left(W_{\mathrm{T}}\right)$ using the slab sizes measured in the TEM 

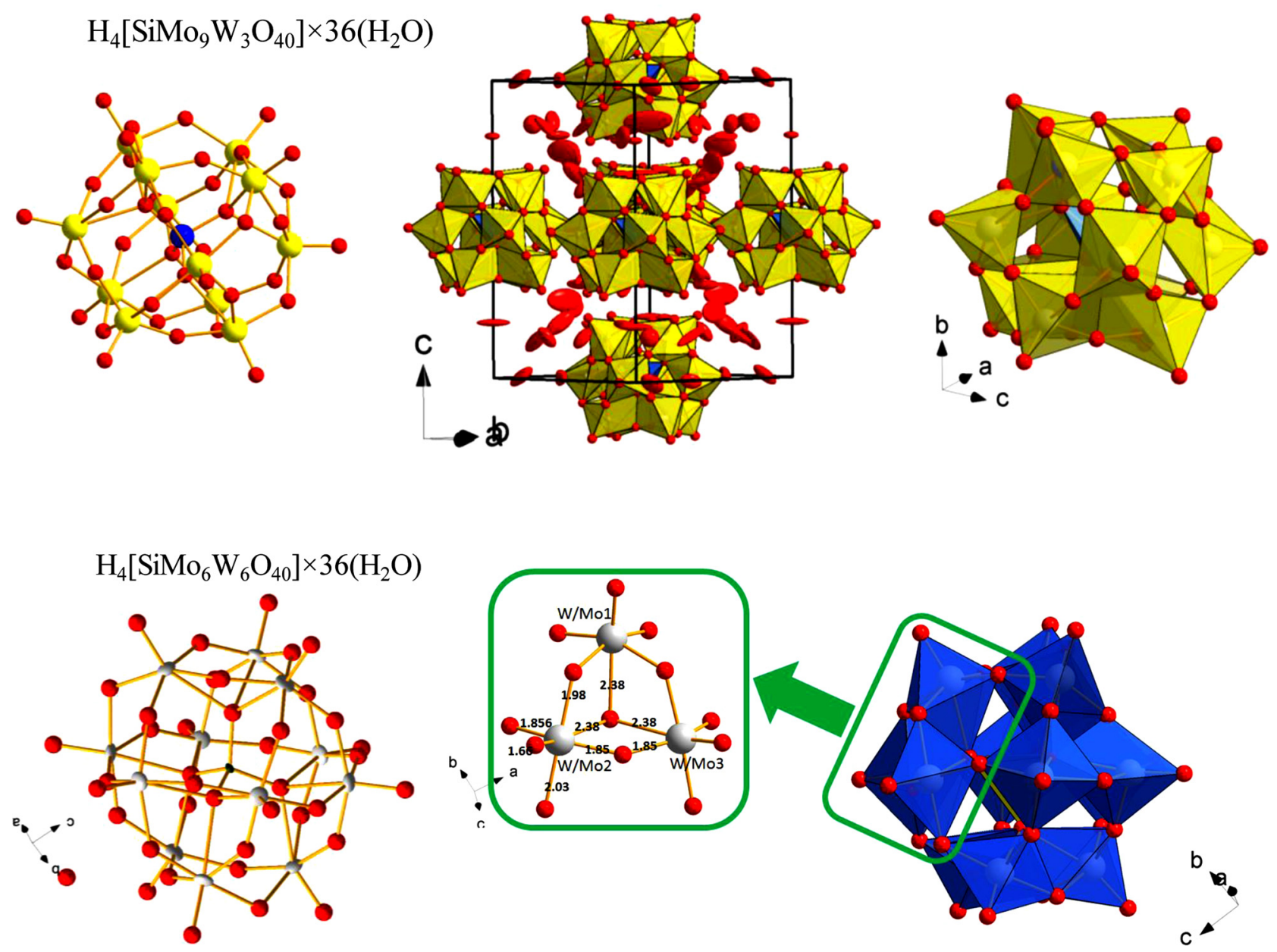

Fig. 3. Crystals and detailed heteropolyanion structures and formation of $\mathrm{H}_{4}\left[\mathrm{SiMo}_{6} \mathrm{~W}_{6} \mathrm{O}_{40}\right] \cdot 36 \mathrm{H}_{2} \mathrm{O}$ and $\mathrm{H}_{4}\left[\mathrm{SiMo}_{9} \mathrm{~W}_{3} \mathrm{O}_{40}\right] 36 \mathrm{H}_{2} \mathrm{O}$.

micrographs:

$D=\frac{W_{\mathrm{e}}+W_{\mathrm{c}}}{W_{\mathrm{T}}}=\frac{\sum_{i=1 . . t} 6 n_{i}-6}{\sum_{i=1 . . t} 3 n_{i}^{2}-3 n_{i}+1}$

where $n_{i}$ is the number of $\mathrm{Mo}(\mathrm{W})$ atoms along one side of the $\mathrm{Mo}(\mathrm{W}) \mathrm{S}_{2}$ slab, as determined by its length, and $t$ is the total number of slabs in the TEM micrograph.

The number of slabs per stack was determined to obtain the average stacking degree $(\bar{N})$ :

$\bar{N}=\frac{\sum_{i=1 . . t} n_{i} N_{i}}{\sum_{i=1 . . t} n}$

where $n_{i}$ is the number of stacks in $N_{i}$ layers.

\subsubsection{X-ray photoelectron spectroscopy (XPS)}

The sulfided catalyst samples were analysed by XPS. The spectra were recorded on a Kratos Axis Ultra DLD spectrometer using a monochromatic $\mathrm{Al} \mathrm{K \alpha}$ source $(\mathrm{hn}=1486.6 \mathrm{eV}, 150 \mathrm{~W})$. The samples were mounted on a holder using double-sided adhesive tape. For the non-conductive samples, the Kratos charge neutraliser system was used and the spectra were charge-corrected to provide the $\mathrm{C} 1 \mathrm{~s}$ spectral component of adventitious carbon (C-C, C-H) at $284.8 \mathrm{eV}$. In addition to the survey photoelectron spectra, narrow spectral regions (Al 2p, S 2p, Mo 3d, W 4f, C 1s and O 1s) were recorded. The binding energy (BE) scale of the spectrometer was preliminarily calibrated using the position of the peaks for the $\mathrm{Au} 4 \mathrm{f}_{7 / 2}(83.96 \mathrm{eV})$ and $\mathrm{Cu} 2 \mathrm{p}_{3 / 2}(932.62 \mathrm{eV})$ core levels of pure metallic gold and copper. The pass energy of the analyser was $160 \mathrm{eV}$ for the survey spectra and $40 \mathrm{eV}$ for the narrow scans. The individual spectral regions were analysed to determine the $\mathrm{BE}$ of the peaks, identify the chemical state of the elements and calculate the relative ratios of the elements on the catalyst surface.

The collected spectra were analysed using the CasaXPS software program (Version 2.3.16) after applying a Shirley background subtraction. Gaussian (30\%) - Lorentzian (70 \%) peaks were used for spectra decomposition. All XPS spectra were carefully decomposed according to previous works $[20,27,28]$.

\subsection{Evaluation of catalytic activities}

The catalytic activity was determined in a flow high-pressure fixedbed microreactor. Prior to testing, the catalysts were sulfided in a flow of $\mathrm{H}_{2} \mathrm{~S} / \mathrm{H}_{2}(10 \mathrm{vol} . \%)$ at atmospheric pressure and $400{ }^{\circ} \mathrm{C}$ for $2 \mathrm{~h} .0 .4 \mathrm{~g}$ of catalyst $(0.25-0.50 \mathrm{~mm})$ was diluted with of low-surface-area sieved carborundum $(0.2-0.4 \mathrm{~mm})$ in a ratio of one to one and placed in isothermal zone of the reactor. Catalysts were tested under the following conditions: $320^{\circ} \mathrm{C}, 3.0 \mathrm{MPa}$ of hydrogen, $10 \mathrm{~h}^{-1}$ liquid hourly space velocity (LHSV) and a $500 \mathrm{~N} \mathrm{~L} \mathrm{~L}^{-1}$ volume ratio of hydrogen to feed. For evaluation of HDS and hydrogenation performances, a mixture of DBT (1000 ppm S), naphthalene (3 wt. \%), hexadecane (as an internal standard, $1 \mathrm{wt} . \%$ ) and toluene (as a solvent) was used. The liquid product compositions of the samples collected every hour were determined using a Crystall-5000 Gas Chromatograph equipped with a 30 m OV-101 column.

The products of reactions were identified by GC/MS analysis using a Finnigan Trace DSQ. All catalysts exhibited stable performance, achieving a steady state after 7-10 h.

The rate constants of the pseudo-first-order reactions of the DBT 


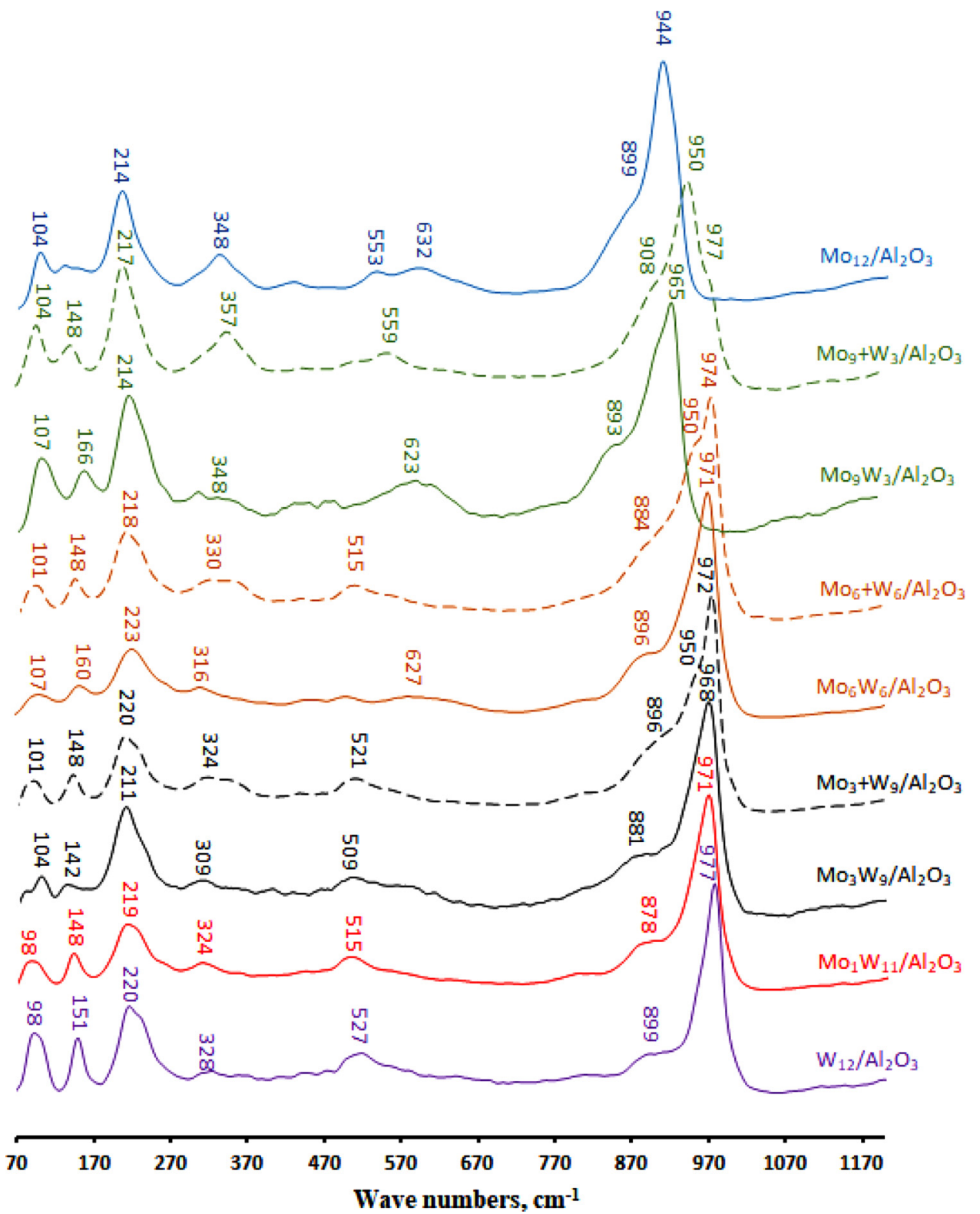

Fig. 4. Raman spectra for oxidic MoW catalysts dried at $110{ }^{\circ} \mathrm{C}$.

HDS and naphthalene HYD were determined using the equations presented in our previous works $[20,27]$.

\section{Results}

\subsection{Characterization of the solids}

\subsubsection{IR- and Raman spectroscopy of $M o_{n} W_{12-n} H P A s$}

IR and Raman spectra of $\mathrm{H}_{4}\left[\mathrm{SiMo}_{\mathrm{n}} \mathrm{W}_{12-\mathrm{n}} \mathrm{O}_{40}\right]$ HPAs (with $\mathrm{n}=1,3,6$ and 9) are presented in Fig. 1 and Fig. 2, respectively. IR and Raman spectra of monometallic and mixed HPAs are very close and present the typical peaks of Keggin structure.

In IR spectra, characteristic peaks assigned to the Keggin structure are observed [29,30], at 913-930 and $957-982 \mathrm{~cm}^{-1}$ for Si-O and Mo (W)- $\mathrm{O}_{\mathrm{t}}$ vibrations stretching mode respectively. together with lines at $867-882$ and $773-780 \mathrm{~cm}^{-1}$ corresponding to $\mathrm{Mo}(\mathrm{W})-\mathrm{O}_{\mathrm{b}}-\mathrm{Mo}(\mathrm{W})$ and $\mathrm{Mo}(\mathrm{W})-\mathrm{O}_{\mathrm{c}}-\mathrm{Mo}(\mathrm{W})$ vibrations. The increase of the Mo content in $\mathrm{Si}$ $\mathrm{Mo}_{\mathrm{n}} \mathrm{W}_{12-\mathrm{n}} \mathrm{O}_{40}{ }^{4-}$ is reflected by a slight increased shift to the lower wavenumbers for $\mathrm{Mo}(\mathrm{W})-\mathrm{O}_{\mathrm{t}}$ and $\mathrm{Mo}(\mathrm{W})-\mathrm{O}_{\mathrm{b}}-\mathrm{Mo}(\mathrm{W})$ lines. All Raman spectra (Fig. 2) are dominated by a main peak corresponding to symmetric $\nu_{\mathrm{s}}\left(\mathrm{Mo}(\mathrm{W})-\mathrm{O}_{\mathrm{t}}\right)$ terminal vibration [29,31,32]. For the high $\mathrm{W}$ content mixed HPA, SiMo ${ }_{1} \mathrm{~W}_{11}$ and $\mathrm{SiMo}_{3} \mathrm{~W}_{9}$ HPAs the position of this line $\left(1005 \mathrm{~cm}^{-1}\right)$ is similar to that observed for $\mathrm{SiW}_{12} \mathrm{O}_{40}$ while a more important shift towards low wavenumbers is observed with the further increase of Mo [33]. An important difference is observed for vibrations $\nu_{\mathrm{s}}\left(\mathrm{W}-\mathrm{O}_{\mathrm{c}}-\mathrm{W}\right)$ and $\nu_{\mathrm{s}}\left(\mathrm{Mo}-\mathrm{O}_{\mathrm{c}}-\mathrm{Mo}\right)$, which correspond to peaks at 552 and $638 \mathrm{~cm}^{-1}$. In the case of spectra for mixed HPAs, a weak peak is observed, which lies between 552 and $638 \mathrm{~cm}^{-1}$, which may indicate the presence of both vibrations and possibly the presence of $\nu_{\mathrm{s}}\left(\mathrm{Mo}-\mathrm{O}_{\mathrm{c}}-\mathrm{W}\right)$ vibrations.

Both Raman and IR analyses seem to be in agreement with the formation of mixed Keggin structure for the new synthesized mixed $\mathrm{SiMo}_{6} \mathrm{~W}_{6}$ and $\mathrm{SiMo}_{9} \mathrm{~W}_{3}$ heteropolyacids. Nevertheless, in order to rebut the formation of separate monometallic HPA, single crystal XRD has been performed for characterization.

\subsubsection{Single-crystal XRD}

The experimental data collection and refinement results are listed in Table 1. Both HPA compounds $\mathrm{SiMo}_{6} \mathrm{~W}_{6}$ and $\mathrm{SiMo}_{9} \mathrm{~W}_{3}$ are isomorphs and crystallize in the tetragonal space group P- $42_{1} \mathrm{c}$. The number of 


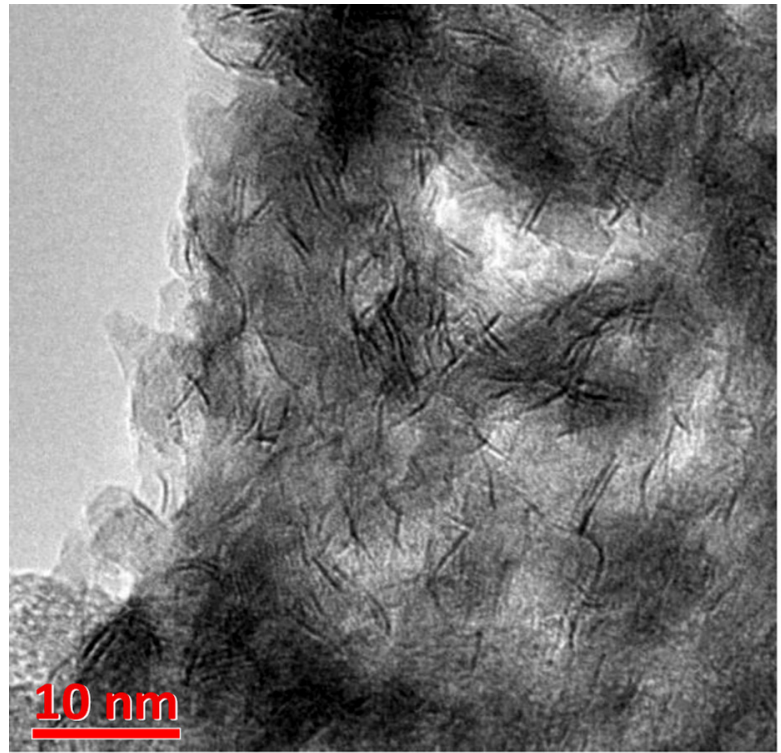

$\mathrm{Mo}_{6} \mathrm{~W}_{6} / \mathrm{Al}_{2} \mathrm{O}_{3}$



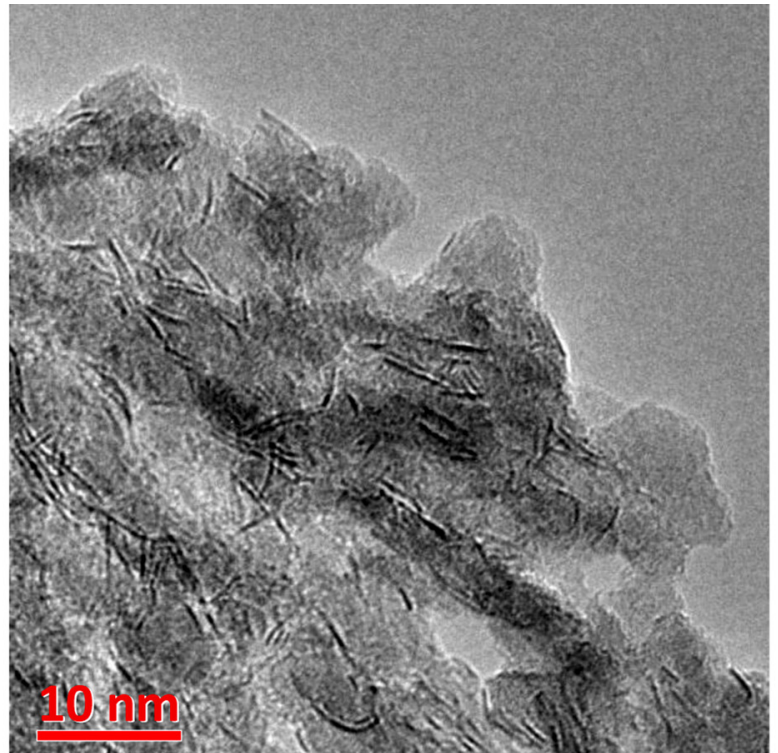

$\mathrm{Mo}_{6}+\mathrm{W}_{6} / \mathrm{Al}_{2} \mathrm{O}_{3}$

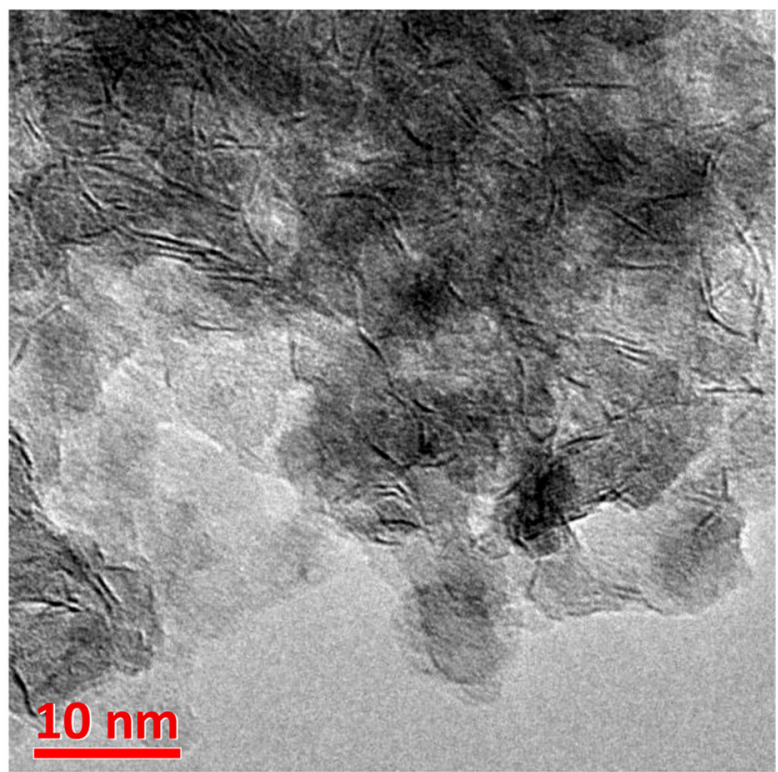

$\mathrm{Mo}_{9}+\mathrm{W}_{3} / \mathrm{Al}_{2} \mathrm{O}_{3}{ }^{*}$

$\mathrm{Mog}_{9} \mathrm{~W}_{3} / \mathrm{Al}_{2} \mathrm{O}_{3}{ }^{*}$

Fig. 5. HRTEM micrographs of sulfided MoW catalysts.

hydration water molecules determined during the structural refinement correspond to 36 molecules per $\mathrm{H}_{4}\left[\mathrm{SiMo}_{\mathrm{n}} \mathrm{W}_{12-\mathrm{n}} \mathrm{O}_{40}\right]$ cluster for the two compounds in agreement with their nearly identical refined lattice parameters. Before going into the structural details, one should note the poor stability of the crystals in air at ambient temperature, even more pronounced for the $\mathrm{H}_{4}\left[\mathrm{SiMo}_{6} \mathrm{~W}_{6} \mathrm{O}_{40}\right]$, polycation for which a single crystal had to be isolated very rapidly and collected at $100 \mathrm{~K}$ in a cold nitrogen flow to prevent from degradation by moisture into an amorphous solid. For the $\mathrm{H}_{4}\left[\mathrm{SiMo}_{9} \mathrm{~W}_{3} \mathrm{O}_{40}\right]$ hydrate a simple protection of the crystals by vacuum grease allows full data collection at room temperature. The two crystal structures are similar and show a distribution of HPA (two per unit cell) separate by ca.12.75 $\AA$ (d(Si-Si)) (Fig. 3b) surrounded by water molecules. These latter have been located on
difference-Fourier maps and show very high thermal parameters which reflect local disorder/off-centering due the proton and Mo/W disorder on the counter molecules (Fig. 3). Residual peaks subsist at the end of the refinement which picture partial water positions but have not been taken into account due to even higher vibrations. Finally, 36 water molecules were found per formula unit in both cases. For both compounds, the Mo/W occupancy and the scale factor parameters are strongly correlated which complicate the determination of the real Mo/ $\mathrm{W}$ ratio during refinement. However, it was checked that fixing the ratio to the preparation stoichiometry leads to best $\mathrm{R} \%$ values together with most reasonable thermal parameters for all atoms. No evidence was found that Mo/W are ordered by three independent positions offered in the crystal structure, contrarily to what occasionally occurs 
Table 3

Morphological characteristics of sulfided $\mathrm{Mo}(\mathrm{W})$ catalysts.

\begin{tabular}{|c|c|c|c|c|c|c|c|c|c|c|c|c|}
\hline \multirow[t]{2}{*}{ Catalyst } & \multirow[t]{2}{*}{$\begin{array}{l}\text { Average length } L^{-} \\
(\mathrm{nm})\end{array}$} & \multirow[t]{2}{*}{$\begin{array}{l}\text { Average stacking } \\
\text { number } N^{-}\end{array}$} & \multirow[t]{2}{*}{$\begin{array}{l}\text { Dispersion of } \mathrm{MoS}_{2} \\
\text { particles } D\end{array}$} & \multicolumn{5}{|c|}{ Distribution of slab length (rel. \%) } & \multicolumn{4}{|c|}{$\begin{array}{l}\text { Distribution of stacking number (rel. } \\
\%)\end{array}$} \\
\hline & & & & $<2 \mathrm{~nm}$ & $2-4 \mathrm{~nm}$ & $4-6 \mathrm{~nm}$ & $6-8 \mathrm{~nm}$ & $>8 \mathrm{~nm}$ & 1 & 2 & 3 & $>4$ \\
\hline $\mathrm{Mo}_{12} / \mathrm{Al}_{2} \mathrm{O}_{3}$ & 3.8 & 1.2 & 0.31 & 3 & 61 & 30 & 5 & 1 & 79 & 18 & 2 & 1 \\
\hline $\mathrm{Mo}_{9} \mathrm{~W}_{3} / \mathrm{Al}_{2} \mathrm{O}_{3}$ & 4.0 & 1.5 & 0.29 & 2 & 49 & 40 & 8 & 1 & 57 & 37 & 4 & 2 \\
\hline $\mathrm{Mo}_{9}+\mathrm{W}_{3} / \mathrm{Al}_{2} \mathrm{O}_{3}$ & 3.6 & 1.2 & 0.32 & 6 & 62 & 29 & 2 & 1 & 82 & 15 & 2 & 1 \\
\hline $\mathrm{Mo}_{6} \mathrm{~W}_{6} / \mathrm{Al}_{2} \mathrm{O}_{3}$ & 3.9 & 1.4 & 0.30 & 3 & 57 & 34 & 5 & 1 & 70 & 24 & 5 & 1 \\
\hline $\mathrm{Mo}_{6}+\mathrm{W}_{6} / \mathrm{Al}_{2} \mathrm{O}_{3}$ & 3.8 & 1.3 & 0.31 & 3 & 58 & 31 & 6 & 2 & 73 & 24 & 2 & 1 \\
\hline $\mathrm{Mo}_{3} \mathrm{~W}_{9} / \mathrm{Al}_{2} \mathrm{O}_{3}$ & 3.8 & 2.0 & 0.34 & 4 & 56 & 36 & 3 & 1 & 34 & 42 & 14 & 10 \\
\hline $\mathrm{Mo}_{3}+\mathrm{W}_{9} / \mathrm{Al}_{2} \mathrm{O}_{3}$ & 3.5 & 2.3 & 0.29 & 6 & 68 & 23 & 2 & 1 & 29 & 29 & 30 & 12 \\
\hline $\mathrm{W}_{12} / \mathrm{Al}_{2} \mathrm{O}_{3}$ & 4.2 & 1.2 & 0.28 & 2 & 46 & 42 & 8 & 2 & 84 & 14 & 2 & - \\
\hline
\end{tabular}

${ }^{\mathrm{a}} \mathrm{MoS}_{2}$ dispersion calculated from HRTEM results.

[19].

Single crystal XRD of $\mathrm{SiMo}_{6} \mathrm{~W}_{6}$ and $\mathrm{SiMo}_{9} \mathrm{~W}_{3}$ HPA allows to conclude that mixed heteropolyanions containing together both $\mathrm{W}$ and Mo atoms were formed.

\subsection{Raman spectroscopy of supported oxidic precursors}

To better understand the behavior of these HPAs after deposition on the support, the Raman analysis was performed and obtained Raman spectra of the oxidic catalysts are shown in Fig. 4. For comparison purposes, Raman spectra of the oxidic precursors prepared from a mixture of monometallic $\mathrm{HPA} \mathrm{SiMo}{ }_{12}$ and $\mathrm{SiW}_{12}$ are also reported in Fig. 4. For precursors prepared from a mixture of HPA, the main Raman line observed around $970 \mathrm{~cm}^{-1}$ and corresponding to $\mathrm{Mo}(\mathrm{W})-\mathrm{O}$ terminal vibrations presents an important shoulder at $950 \mathrm{~cm}^{-1}$, increasing with Mo content, witnessing to the presence of Keggin entities with other species. $\mathrm{Mo}_{12} / \mathrm{Al}_{2} \mathrm{O}_{3}$ presents in fact the Raman spectrum of the well-known $\mathrm{AlMo}_{6} \mathrm{O}_{24} \mathrm{H}_{6}{ }^{3-}$ Anderson heteropolyanion species (noted $\mathrm{AlMo}_{6}$ )in agreement with results previously reported [34,35]. For oxidic catalysts prepared from a mixture of $\mathrm{SiW}_{12}$ and $\mathrm{SiMo}_{12} \mathrm{HPA}$, the shoulder noticed at $950 \mathrm{~cm}^{-1}$ is then due to the $\mathrm{AlMo}_{6}$ formation from instable $\mathrm{SiMo}_{12}$ species when deposited on alumina due to the "buffer effect" of alumina and $\mathrm{Al}^{3+}$ extraction from the support [36,37]. For the corresponding catalysts prepared from mixed $\mathrm{HPAs}\left(\mathrm{SiMo}_{9} \mathrm{~W}_{3}\right.$, $\mathrm{SiMo}_{6} \mathrm{~W}_{6}$ and $\mathrm{SiMo}_{3} \mathrm{~W}_{9}$ ) the shoulder is not observed. It is in agreement with the use of a mixed $\mathrm{SiMo}_{\mathrm{n}} \mathrm{W}_{12-\mathrm{n}}$ HPA more stable on alumina support than the $\mathrm{SiMo}_{12}$ one. A shift of the main peaks is also observed with the increase of molybdenum content, as was previously noted on Raman and IR spectra of bulk HPAs. Moreover, analysis of the low Raman shift region (below $230 \mathrm{~cm}^{-1}$ ) shows lines similar in shape and position for the bulk and the corresponding Keggin W-based HPA catalysts [29], except for $\mathrm{Mo}_{9} \mathrm{~W}_{3} / \mathrm{Al}_{2} \mathrm{O}_{3}$ and $\mathrm{Mo}_{9}+\mathrm{W}_{3} / \mathrm{Al}_{2} \mathrm{O}_{3}$ ones, in which the proportion of molybdenum is much higher. In this case, all peaks are shifted to the low wavenumbers. As already noted, for the Wbased catalysts, after drying, a shift from 1007 to $977 \mathrm{~cm}^{-1}$ of the main line $\left(\mathrm{W}-\mathrm{O}_{\mathrm{t}}\right.$ vibration) towards lower wavenumbers due to interaction with the support is observed [19]. According to the obtained spectral data, it can be assumed that the mixed MoW structure is preserved even after maturation and drying.

\subsection{Characterization of supported $\mathrm{Mo}(\mathrm{W}) / \mathrm{Al}_{2} \mathrm{O}_{3}$ sulfide catalysts}

\subsubsection{HRTEM}

All catalysts were characterized by HRTEM to obtain more information about the dispersion of $\mathrm{Mo}(\mathrm{W}) \mathrm{S}_{2}$ active phase. The HRTEM micrographs are shown in Fig. 5. The observed black slabs correspond to $\mathrm{Mo}(\mathrm{W}) \mathrm{S}_{2}$ crystallites with $0.65 \mathrm{~nm}$ interplanar distances. For each catalyst, the distributions in stacking degree and length of the $\mathrm{Mo}(\mathrm{W}) \mathrm{S}_{2}$ slabs were determined, as well as the corresponding average values, presented in Table 3 . The average particle length and stacking number ranged from 3.6 to $4.2 \mathrm{~nm}$ and from 1.2 to 2.3 , respectively. The highest number stacking value corresponds to $\mathrm{Mo}_{3}+\mathrm{W}_{9} / \mathrm{Al}_{2} \mathrm{O}_{3}$ catalyst. The increase in molybdenum percentage led to a simultaneous decrease the stacking number of $\mathrm{Mo}(\mathrm{W}) \mathrm{S}_{2}$ active phase particles (from 2.3 to 1.2) for $\mathrm{Mo}_{\mathrm{n}}+\mathrm{W}_{\mathrm{n}-12} / \mathrm{Al}_{2} \mathrm{O}_{3}$ catalysts. The dispersion of the active phase varies between 0.28 and 0.34 . Moreover, the dispersion of the active phase of mixed $\mathrm{Mo}_{\mathrm{n}} \mathrm{W}_{12-\mathrm{n}}$ catalysts decreased from 0.34 to 0.29 with increasing $\mathrm{Mo} / \mathrm{W}$ ratio from $3 / 9$ to $9 / 3$, while it increased from 0.29 to 0.32 for the ones based on the mixture HPAs counterparts.

\subsection{2. $H A A D F$}

Typical HAADF images of sulfided $\mathrm{Mo}_{3} \mathrm{~W}_{9} / \mathrm{Al}_{2} \mathrm{O}_{3}, \mathrm{Mo}_{6} \mathrm{~W}_{6} / \mathrm{Al}_{2} \mathrm{O}_{3}$ and $\mathrm{Mo}_{9} \mathrm{~W}_{3} / \mathrm{Al}_{2} \mathrm{O}_{3}$ catalysts are presented in Fig. 6. One advantage of HAADF is that it allows to discriminate between Mo and $\mathrm{W}$ atoms due to their difference in atomic number as already evidenced in a previous study [18]. The intensity in HAADF images, for a given thickness and density and depending on the collection angles, is a function of the atomic number. Therefore, $\mathrm{W}$ atoms appear brighter than Mo atoms in the HAADF images. The most attention was paid to the monolayer particles and their structure. In the case of the $\mathrm{Mo}_{6} \mathrm{~W}_{6} / \mathrm{Al}_{2} \mathrm{O}_{3}$ sample, as well as for the $\mathrm{Mo}_{3} \mathrm{~W}_{9} / \mathrm{Al}_{2} \mathrm{O}_{3}$ [20], mixed slabs are formed in which the molybdenum atoms are concentrated in a core, and the tungsten atoms are located in a shell. At the same time, tungsten atoms are localized at the edges of the slab and formed a rim around molybdenum atoms. The $\mathrm{Mo}_{9} \mathrm{~W}_{3} / \mathrm{Al}_{2} \mathrm{O}_{3}$ sample was characterized by a disordered structure of the active phase, where the two-dimensional foils can be represented as $\mathrm{MoS}_{2}$ particles with small inclusions of $\mathrm{W}$ atoms. Perhaps this can be explained by the different kinetics of sulfidation of Mo and $\mathrm{W}$ atoms and an excess of the former in the structure. According to the data obtained by HAADF imaging, it can be concluded that the structure of mixed $\mathrm{MoWS}_{2}$ particles depends on the ratio of molybdenum and tungsten in the structure. Therefore, when the content of Mo increases from 50 (in $\mathrm{Mo}_{6} \mathrm{~W}_{6} / \mathrm{Al}_{2} \mathrm{O}_{3}$ catalyst) to 75 at $\%$ (in $\mathrm{Mo}_{9} \mathrm{~W}_{3} / \mathrm{Al}_{2} \mathrm{O}_{3}$ ), a transition occurs from an ordered core-shell structure to a disordered structure in which tungsten atoms are randomly located.

\subsubsection{XPS spectroscopy}

Information about the composition of sulfide particles on the surface of the synthesized catalysts was obtained in detail by XPS. The XPS spectra of $\mathrm{Mo}_{\mathrm{n}} \mathrm{W}_{12-\mathrm{n}} / \mathrm{Al}_{2} \mathrm{O}_{3}$ and $\mathrm{Mo}_{\mathrm{n}}+\mathrm{W}_{12-\mathrm{n}} / \mathrm{Al}_{2} \mathrm{O}_{3}$ were decomposed thanks to previous works $[20,27,28]$ using the appropriate oxide and sulfided references as supported monometallic catalysts for example (Fig. 7). The Mo3d spectra contain three doublets: $229.0 \mathrm{eV}$ and 232.0 $\mathrm{eV}$ correspond to $\mathrm{Mo}_{5 / 2}$ and $\mathrm{Mo}_{5} \mathrm{~d}_{3 / 2}$ of $\mathrm{Mo}^{4+}$ ( $\mathrm{MoS}_{2}$ species), doublet at about 230.0 and $233.5 \mathrm{eV}$ is related to $\mathrm{Mo}^{5+}\left(\mathrm{MoO}_{\mathrm{x}} \mathrm{S}_{\mathrm{y}}\right.$ species) and doublet at 232.5 and $235.7 \mathrm{eV}$ is associated with $\mathrm{Mo}^{6+}$ oxide species.

The W 4f spectra contain three $\mathrm{W}$ 4f doublets: the doublet with binding energies (BE) at 32.1 and $34.3 \mathrm{eV}$ is associated to $\mathrm{W}_{4} \mathrm{f}_{7 / 2}$ and $\mathrm{W}_{4} \mathrm{f}_{5 / 2}$ of $\mathrm{W}^{4+}$ species of the $\mathrm{WS}_{2}$ phase, the doublet with binding 


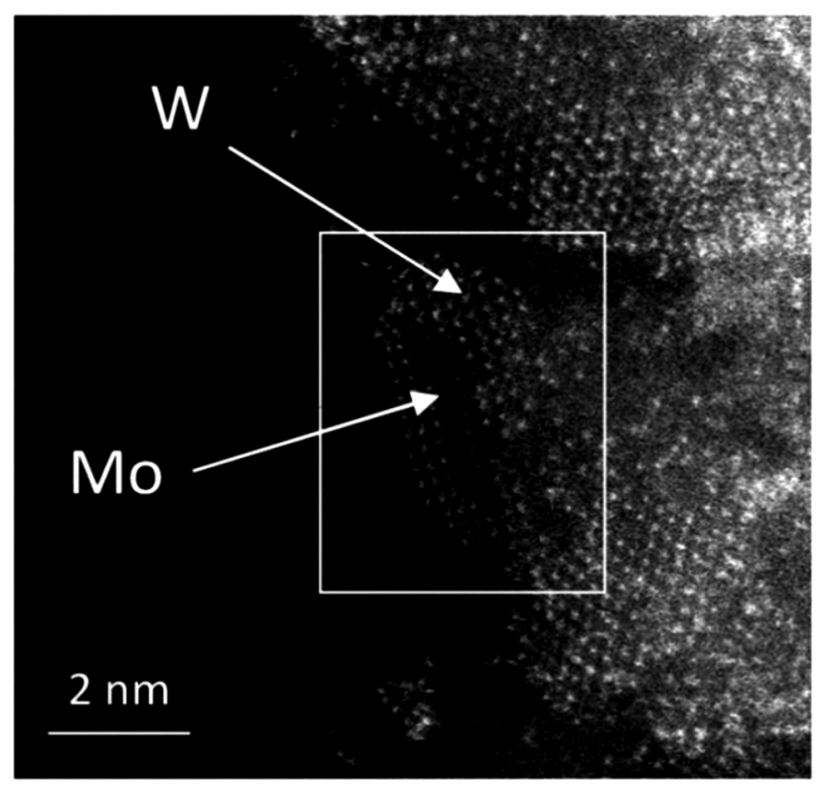

$\mathrm{Mo}_{3} \mathrm{~W}_{\mathbf{9}} / \mathrm{Al}_{2} \mathrm{O}_{3}{ }^{*}$

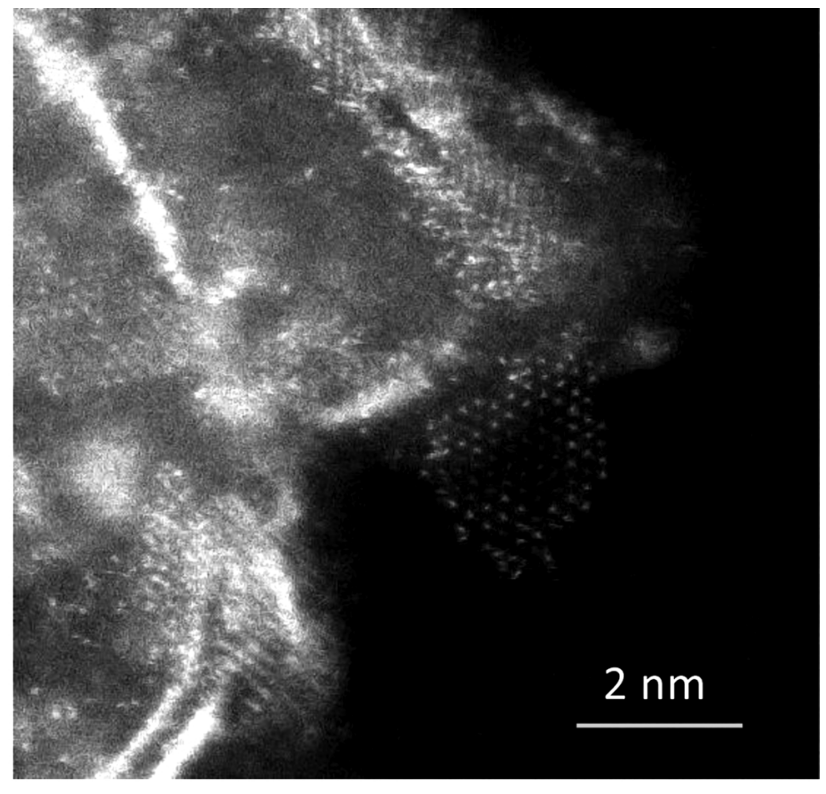

$\mathrm{Mo}_{6} \mathrm{~W}_{6} / \mathrm{Al}_{2} \mathrm{O}_{3}$



\section{$\mathrm{Mog}_{9} \mathrm{~W}_{3} / \mathrm{Al}_{2} \mathrm{O}_{3}$}

Fig. 6. HAADF images of sulfided MoW catalysts.

* adapted from [20].

energies at 33.0 and $35.2 \mathrm{eV}$ to $\mathrm{W}^{5+}$ species of a $\mathrm{WS}_{\mathrm{x}} \mathrm{O}_{\mathrm{y}}$ oxysulfide species, and finally the doublet with binding energies at 36.0 and 37.9 $\mathrm{eV}$ correlated with $\mathrm{W}^{6+}$ oxide species. It should also be kept in mind that the $\mathrm{W}_{5} \mathrm{p}_{3 / 2}$ and Mo4p ranges (non splitted level) overlap the W4f levels. The contributions of these peaks were excluded when calculating the true content of W4f fractions. All the constraints between BE, FWHM and the peak areas of Mo4p and Mo3d $\mathrm{d}_{3 / 2}$ were determined experimentally by XPS analysis of the $\mathrm{Mo}_{12} / \mathrm{Al}_{2} \mathrm{O}_{3}$ oxide catalyst.

The results of the XPS decomposition for the metal fractions of molybdenum and tungsten species of the sulfided $\mathrm{Mo}_{\mathrm{n}} \mathrm{W}_{12-\mathrm{n}} / \mathrm{Al}_{2} \mathrm{O}_{3}$ and $\mathrm{Mo}_{\mathrm{n}}+\mathrm{W}_{12-\mathrm{n}} / \mathrm{Al}_{2} \mathrm{O}_{3}$ are reported in Table 4. In all bimetallic catalysts, the sulfidation degree of molybdenum and tungsten were higher than
80 and 58 rel. \% respectively leading to an increase of sufidation compared to those of Mo (70\% rel. \%) and W (51 \% rel. \%) in monometallic catalysts. It should be noted that the sulfidation degree of Mo and $\mathrm{W}$ in mixed $\mathrm{Mo}_{\mathrm{n}} \mathrm{W}_{12-\mathrm{n}} / \mathrm{Al}_{2} \mathrm{O}_{3}$ catalysts was higher than in bimetallic $\mathrm{Mo}_{\mathrm{n}}+\mathrm{W}_{12-\mathrm{n}} / \mathrm{Al}_{2} \mathrm{O}_{3}$ samples prepared from mixture of HPAs except in the case of $\mathrm{W}$ sufidation for $\mathrm{Mo}_{3} \mathrm{~W}_{9}$ catalyst. The highest values (91 rel. \%) of the Mo degree of sulfidation correspond to $\mathrm{Mo}_{6} \mathrm{~W}_{6} / \mathrm{Al}_{2} \mathrm{O}_{3}$ and $\mathrm{Mo}_{9} \mathrm{~W}_{3} / \mathrm{Al}_{2} \mathrm{O}_{3}$ mixed catalysts. Moreover, the $\mathrm{Mo}_{9} \mathrm{~W}_{3} / \mathrm{Al}_{2} \mathrm{O}_{3}$ catalyst also corresponds to the highest degree of tungsten sulfidation equal to 85 rel. \%. Replacing a quarter of the Mo atoms with $\mathrm{W}$ made it possible to increase the sulfidation degree by more than 20 rel. \% for Mo compared to $\mathrm{Mo}_{12} / \mathrm{Al}_{2} \mathrm{O}_{3}$ catalyst while increasing (24 

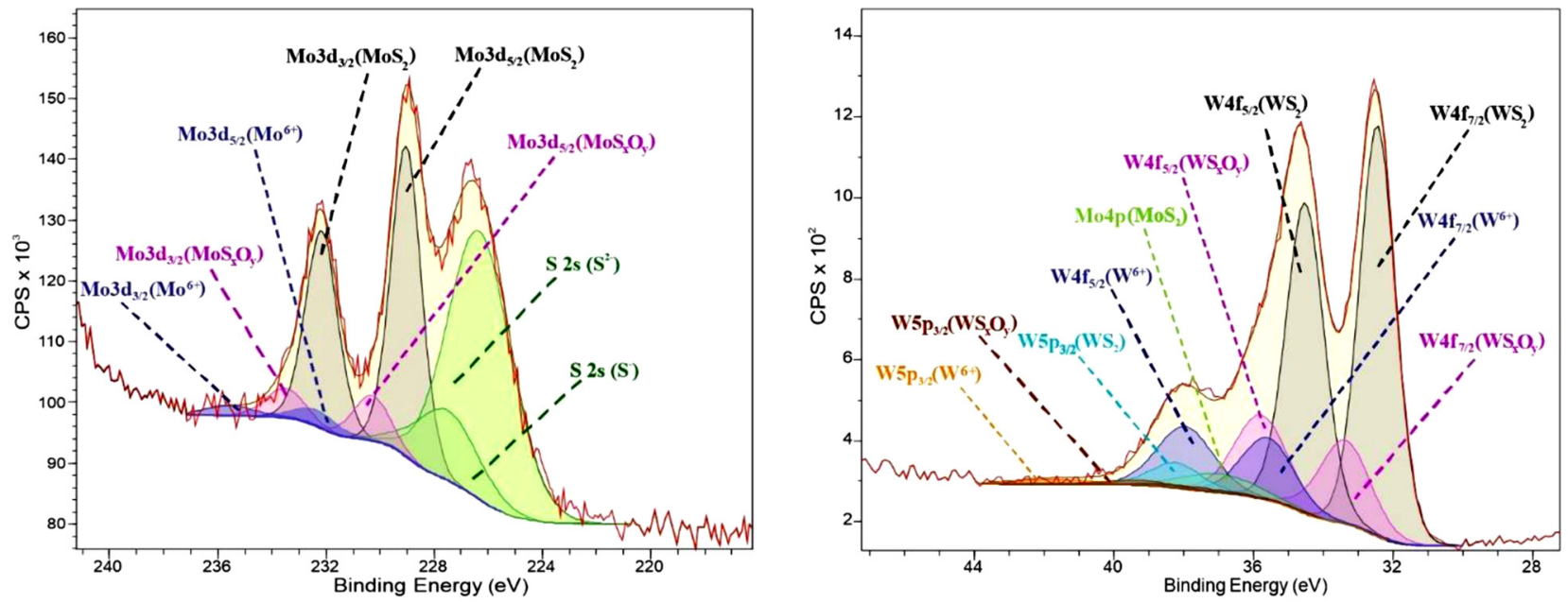

$\mathrm{Mo}_{3} \mathrm{~W}_{9} / \mathrm{Al}_{2} \mathrm{O}_{3}$
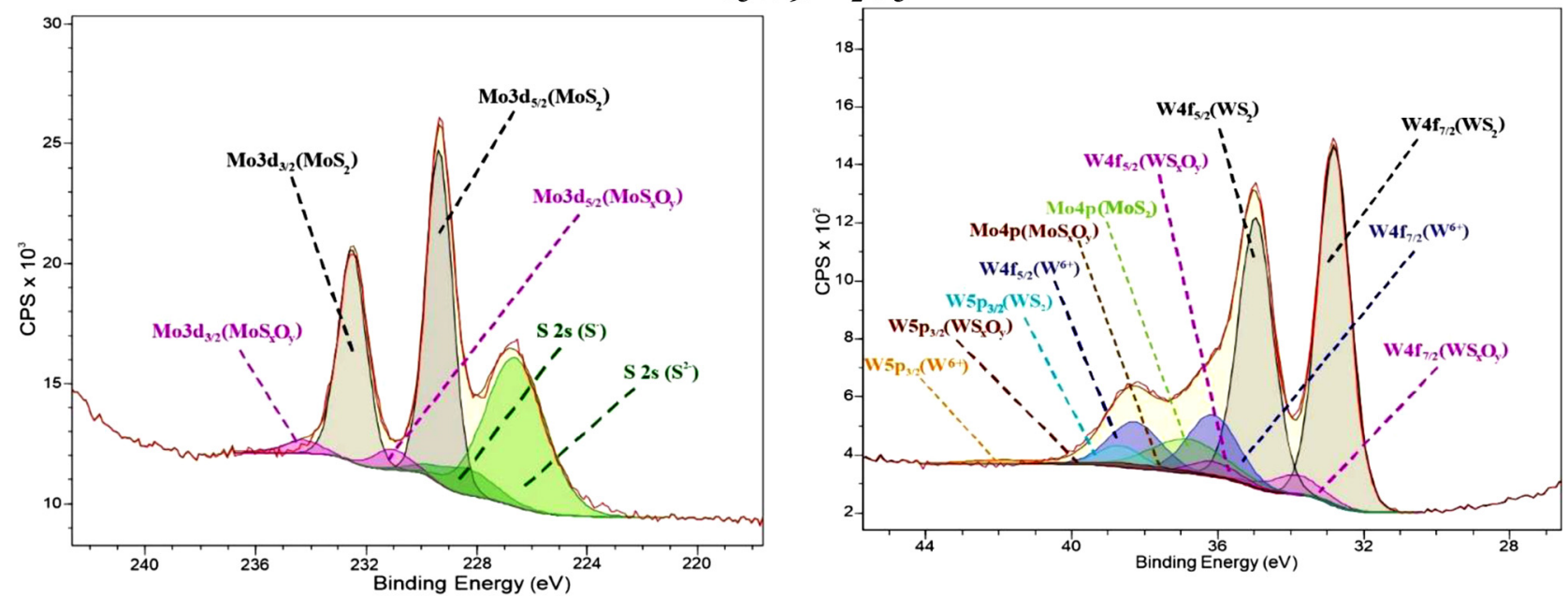

$\mathrm{Mo}_{6} \mathrm{~W}_{6} / \mathrm{Al}_{2} \mathrm{O}_{3}$


$\mathrm{Mog}_{9} \mathrm{~W}_{3} / \mathrm{Al}_{2} \mathrm{O}_{3}$

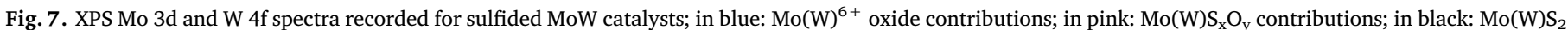



rel. \%) that of W. Sulfidation of molybdenum oxide occurs at lower temperatures, while tungsten oxide sulfides at higher temperatures due to thermodynamics and lower reactivity [38]. As already noted, sulfidation of MoW catalysts begins with the formation of $\mathrm{MoS}_{2}$ nuclei, which contribute to the activation of $\mathrm{H}_{2} \mathrm{~S}$, which allows increasing the degree of sulfidation of oxidic tungsten species and raising the number of active sites [18]. Moreover, this effect is enhanced by the use of mixed HPAs as oxide precursors of the active phase, as shown in previous works $[18,20]$. It can be explained by the proximity of Mo and $\mathrm{W}$ atoms in the HPA structure. 
Table 4

Metal distribution for Mo and W species present at the surface of sulfided Mo(W) catalysts.

\begin{tabular}{|c|c|c|c|c|c|c|c|c|c|}
\hline \multirow[t]{2}{*}{ Catalyst } & \multicolumn{3}{|c|}{ Mo percentage (rel. \%) } & \multicolumn{3}{|c|}{ W percentage (rel. \%) } & \multicolumn{3}{|c|}{ Number of edge sites $\left(10^{20}\right.$ at $\left.\mathrm{g}^{-1}\right)$} \\
\hline & $\mathrm{MoS}_{2}$ & $\mathrm{MoS}_{\mathrm{x}} \mathrm{O}_{\mathrm{y}}$ & $\mathrm{Mo}^{6+}$ & $\mathrm{WS}_{2}$ & $\mathrm{WS}_{\mathrm{x}} \mathrm{O}_{\mathrm{y}}$ & $\mathrm{W}^{6+}$ & $M o_{\text {edge }}^{I V}$ & $W_{\text {edge }}^{I V}$ & $\sum M o_{\text {edge }}^{I V}+W_{\text {edge }}^{I V}$ \\
\hline $\mathrm{Mo}_{12} / \mathrm{Al}_{2} \mathrm{O}_{3}$ * & 70 & 15 & 15 & - & - & - & 0.88 & - & 0.88 \\
\hline $\mathrm{Mo}_{9} \mathrm{~W}_{3} / \mathrm{Al}_{2} \mathrm{O}_{3}$ & 91 & 7 & 2 & 85 & 3 & 12 & 0.82 & 0.60 & 1.42 \\
\hline $\mathrm{Mo}_{9}+\mathrm{W}_{3} / \mathrm{Al}_{2} \mathrm{O}_{3}$ & 83 & 11 & 6 & 71 & 6 & 23 & 0.87 & 0.59 & 1.46 \\
\hline $\mathrm{Mo}_{6} \mathrm{~W}_{6} / \mathrm{Al}_{2} \mathrm{O}_{3}$ & 91 & 7 & 1 & 76 & 5 & 19 & 0.61 & 0.80 & 1.40 \\
\hline $\mathrm{Mo}_{6}+\mathrm{W}_{6} / \mathrm{Al}_{2} \mathrm{O}_{3}$ & 81 & 16 & 3 & 64 & 18 & 19 & 0.63 & 0.80 & 1.43 \\
\hline $\mathrm{Mo}_{3} \mathrm{~W}_{9} / \mathrm{Al}_{2} \mathrm{O}_{3}{ }^{*}$ & 89 & 2 & 9 & 58 & 8 & 34 & 0.23 & 0.94 & 1.17 \\
\hline $\mathrm{Mo}_{3}+\mathrm{W}_{9} / \mathrm{Al}_{2} \mathrm{O}_{3}$ & 90 & 8 & 2 & 77 & 11 & 12 & 0.48 & 0.74 & 1.22 \\
\hline $\mathrm{W}_{12} / \mathrm{Al}_{2} \mathrm{O}_{3}{ }^{*}$ & - & - & - & 51 & 16 & 33 & - & 0.98 & 0.98 \\
\hline
\end{tabular}

* adapted from [20].

Table 5

Catalytic properties of supported MoW catalysts in the hydrotreating of DBT and naphthalene.

\begin{tabular}{|c|c|c|c|c|c|}
\hline \multirow[t]{2}{*}{ Catalyst } & \multicolumn{2}{|c|}{ Conversion (\%) } & \multicolumn{2}{|c|}{$\begin{array}{l}\text { Reaction rate } \\
\text { constant } \\
\times 10^{5} \mathrm{~mol} \mathrm{~h}^{-1} \\
\mathrm{~g}^{-1} \text { ) }\end{array}$} & \multirow[t]{2}{*}{$S_{\mathrm{HYD} / \mathrm{DDS}}$} \\
\hline & DBT HDS & Naphthalene HYD & $k_{\mathrm{HDS}}$ & $k_{\mathrm{HYD}}$ & \\
\hline $\mathrm{Mo}_{12} / \mathrm{Al}_{2} \mathrm{O}_{3}{ }^{*}$ & 51.9 & 40.5 & 45 & 157 & 1.73 \\
\hline $\mathrm{Mo}_{9} \mathrm{~W}_{3} / \mathrm{Al}_{2} \mathrm{O}_{3}$ & 59.2 & 55.2 & 55 & 244 & 2.83 \\
\hline $\mathrm{Mo}_{9}+\mathrm{W}_{3} / \mathrm{Al}_{2} \mathrm{O}_{3}$ & 44.3 & 39.6 & 36 & 153 & 2.51 \\
\hline $\mathrm{Mo}_{6} \mathrm{~W}_{6} / \mathrm{Al}_{2} \mathrm{O}_{3}$ & 61.3 & 57.3 & 59 & 258 & 3.16 \\
\hline $\mathrm{Mo}_{6}+\mathrm{W}_{6} / \mathrm{Al}_{2} \mathrm{O}_{3}$ & 47.6 & 42.2 & 40 & 166 & 2.33 \\
\hline $\mathrm{Mo}_{3} \mathrm{~W}_{9} / \mathrm{Al}_{2} \mathrm{O}_{3}{ }^{*}$ & 52.9 & 47.5 & 46 & 195 & 3.18 \\
\hline $\mathrm{Mo}_{3}+\mathrm{W}_{9} / \mathrm{Al}_{2} \mathrm{O}_{3}$ * & 32.1 & 27.3 & 24 & 97 & 1.76 \\
\hline $\mathrm{W}_{12} / \mathrm{Al}_{2} \mathrm{O}_{3}{ }^{*}$ & 22.2 & 23.8 & 15 & 82 & 2.61 \\
\hline
\end{tabular}

* adapted from [20].

To calculate the number of edge sites (Table 4), only the mass percentage of $\mathrm{MoS}_{2}\left(\mathrm{WS}_{2}\right)$ obtained from the XPS data and dispersion were taken into account. This made it possible to estimate in a general way the number of active centers in $\mathrm{MoS}_{2}$ and $\mathrm{WS}_{2}$ separate crystallites. At this stage, the formation of a mixed $\mathrm{MoWS}_{2}$ phase demonstrated by HAADF offering possibly MoWS mixed sites is not considered. Since the dispersion of the active phase for all catalysts was approximately equal, the key effect on the number of edge centers was exerted only by the sulfidation degree of metals. An increase in the molybdenum content (until Mo/Mo $+\mathrm{W}=0.5$ ) leads to an increase in the content of edge sites for both types of catalysts due to the high degree of sulfidation of both metals, resulting from synergistic effect between Mo and $\mathrm{W}$ sulfidation, described in detail by Nikulshina et al. [39].

\subsection{Catalytic activities}

The catalytic activities of the sulfided $\mathrm{Mo}_{\mathrm{n}} \mathrm{W}_{12-\mathrm{n}} / \mathrm{Al}_{2} \mathrm{O}_{3}$ and $\mathrm{Mo}_{\mathrm{n}}$ $+\mathrm{W}_{12-\mathrm{n}} / \mathrm{Al}_{2} \mathrm{O}_{3}$ catalysts in co-HDT of DBT and naphthalene are presented in Table 5. The reactants conversions varied in a wide range, from 20.6 to $61.3 \%$ for HDS of DBT and from 23.8 to $57.3 \%$ for HYD of naphthalene over all prepared catalysts. The $\mathrm{W}_{12} / \mathrm{Al}_{2} \mathrm{O}_{3}$ sample demonstrated the lowest activities in DBT HDS (22.2 \%) and in naphthalene HYD (23.8 \%). All $\mathrm{Mo}_{\mathrm{n}}+\mathrm{W}_{12-\mathrm{n}} / \mathrm{Al}_{2} \mathrm{O}_{3}$ catalysts prepared from two monometallic HPA demonstrated a lower activity than the monometallic $\mathrm{Mo}_{12} / \mathrm{Al}_{2} \mathrm{O}_{3}$ sample in HDS DBT. It was noted that with an increase in the Mo/W ratio of 0.33 or more, an increase in catalytic activity occurs in both HDS and HYD reactions (Fig. 8). An increase in $\mathrm{Mo} /(\mathrm{Mo}+\mathrm{W})$ molar ratio above 0.5 contributes to a decrease in catalytic activity. The highest effect was observed for the $\mathrm{Mo}_{6} \mathrm{~W}_{6} / \mathrm{Al}_{2} \mathrm{O}_{3}$ sample which is more than $15 \%$ active in DBT HDS and naphthalene HYD than analogues prepared from a mixture of monometallic heteropolyacids with the same molar ratio.

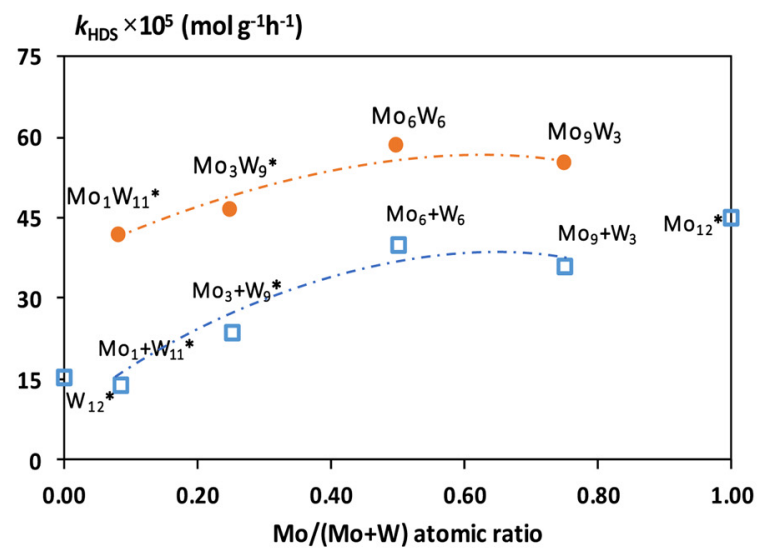

(a)

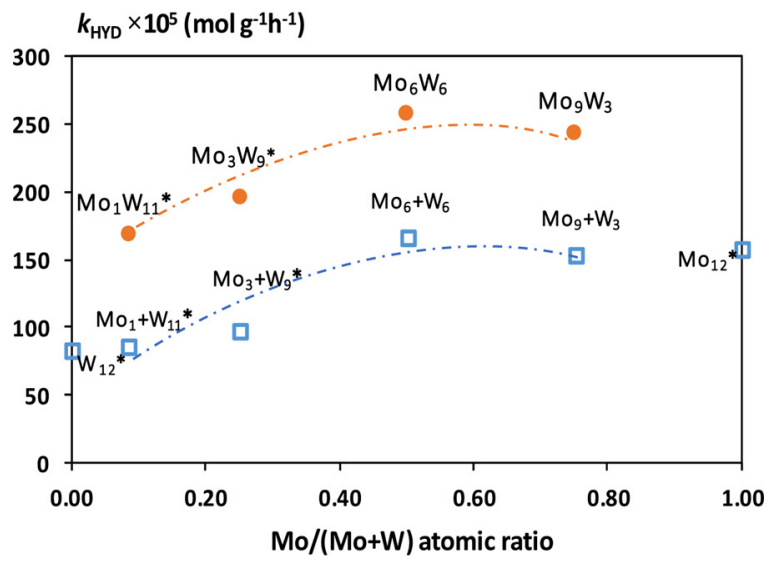

(b)

Fig. 8. Dependence of reaction rate constants in DBT HDS (a) and naphthalene HYD (b) on Mo/(Mo + W) atomic in MoW catalysts (circles correspond to mixed MoW catalysts prepared from mixed $\mathrm{SiMo}_{\mathrm{n}} \mathrm{W}_{12-\mathrm{n}} \mathrm{HPA}$; squares are mixed Mo + W catalysts prepared from a mixture of $\mathrm{SiMo}_{12}$ and $\mathrm{SiW}_{12} \mathrm{HPA}$ ). * adapted from [20].

\section{Discussion}

All analyzed catalysts have similar textural characteristics (Table 2) and dispersion of the active phase particles (Table 3). It should be noted that the replacement of one atom of tungsten by molybdenum atom is a sharp increase an average stacking number (Fig. 9) due to the change of the metal sulfidation rate, which is also reflected in the XPS results. 


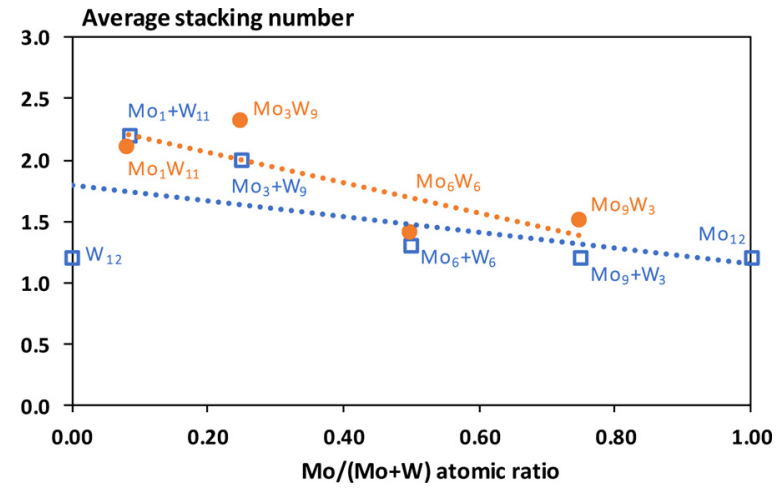

Fig. 9. Dependence of average stacking number on $\mathrm{Mo} /(\mathrm{Mo}+\mathrm{W})$ ratio in $\mathrm{MoW}$ catalysts (circles correspond to mixed MoW catalysts prepared from mixed $\mathrm{SiMo}_{\mathrm{n}} \mathrm{W}_{12-\mathrm{n}} \mathrm{HPA}$; squares are mixed Mo $+\mathrm{W}$ catalysts prepared from a mixture of $\mathrm{SiMo}_{12}$ and $\mathrm{SiW}_{12} \mathrm{HPA}$ ).

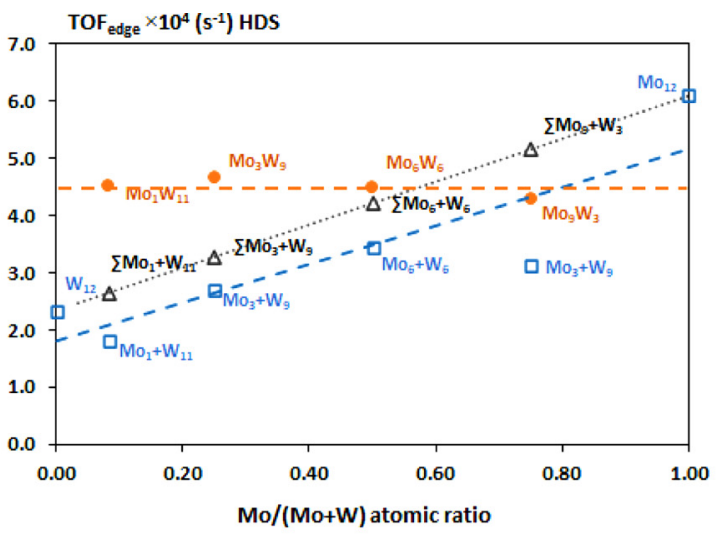

(a)

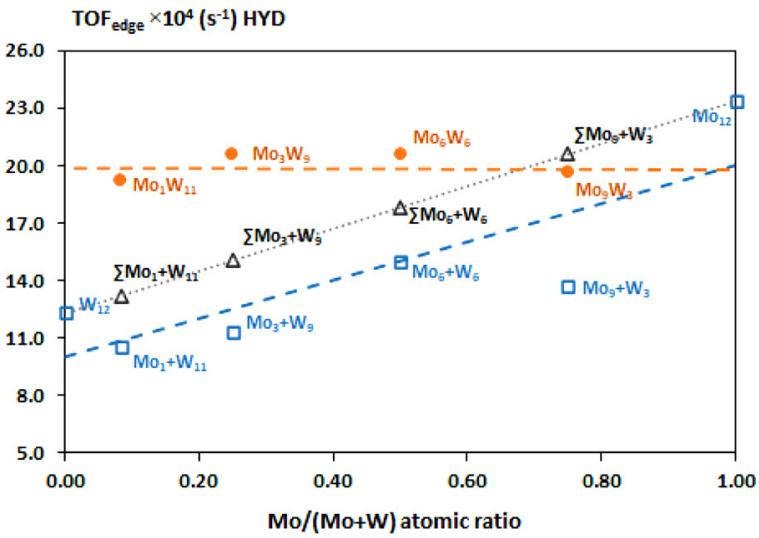

(b)

Fig. 10. Dependence of TOF edge number in DBT HDS (a) and naphthalene HYD (b) on $\mathrm{Mo} /(\mathrm{Mo}+\mathrm{W})$ atomic ratio in MoW catalysts; (circles correspond to mixed MoW catalysts prepared from mixed $\mathrm{SiMo}_{\mathrm{n}} \mathrm{W}_{12-\mathrm{n}} \mathrm{HPA}$; squares are mixed $\mathrm{Mo}+\mathrm{W}$ catalysts prepared from a mixture of $\mathrm{SiMo}_{12}$ and $\mathrm{SiW}_{12} \mathrm{HPA}$; triangles are the additive quantities which were calculated using the values for monometallic $\mathrm{Mo}_{12} / \mathrm{Al}_{2} \mathrm{O}_{3}$ and $\mathrm{W}_{12} / \mathrm{Al}_{2} \mathrm{O}_{3}$ ).

Further, with an increase in the molybdenum content in the catalyst, a gradual decrease in the number of layers occurs, regardless of the type of oxide precursor of the active phase. This can be explained by the fact that there is an interaction between the molybdenum oxide particles and the surface of support $[40,41]$, which were observed on the Raman spectra. This leads to the formation of particles with fewer layers in the

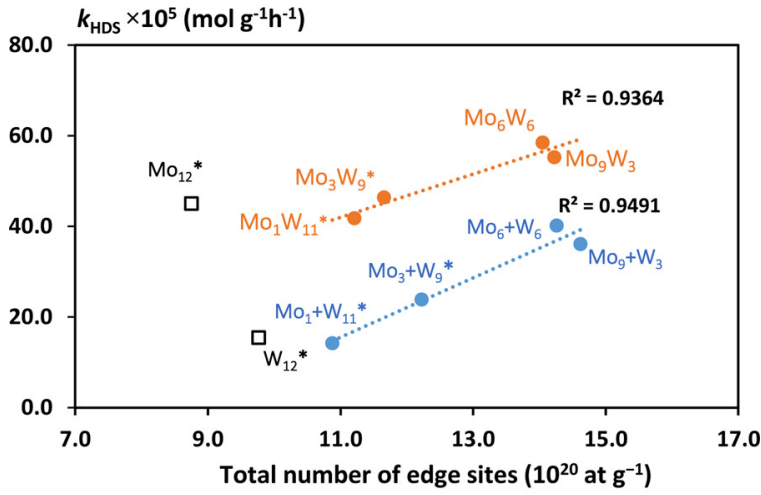

(a)

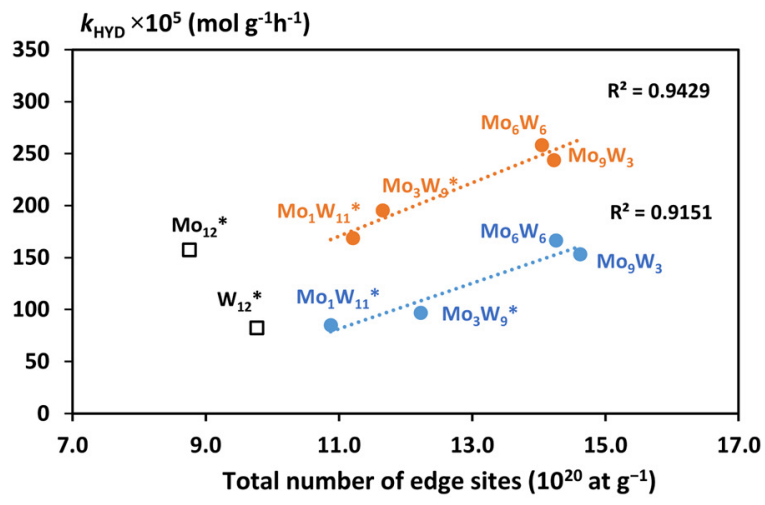

(b)

Fig. 11. Dependence of DBT HDS (a) and naphthalene HYD (b) rate constants on total number of edge sites.

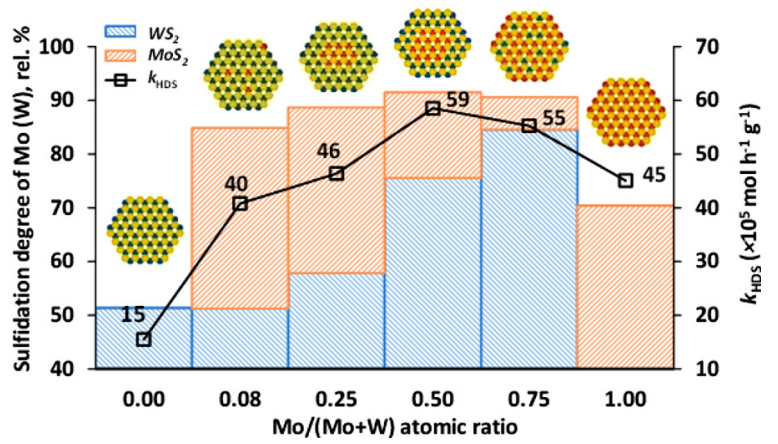

Fig. 12. Relationships between sulfidation degree of Mo (W) in $\mathrm{MoW} / \mathrm{Al}_{2} \mathrm{O}_{3}$ catalysts, their HDS activity and $\mathrm{Mo} /(\mathrm{Mo}+\mathrm{W})$ atomic ratio. The active phase models are based on HAADF.

package, which is also consistent with literature [42].

As we can see from Fig. 8, the catalytic activity increases with the molybdenum content and reaches a maximum with a Mo/(Mo $+\mathrm{W})$ ratio of 0.5. Similar dependencies for CoMoW/SBA-15 catalysts prepared from AHT, AMT and cobalt nitrate hexahydrate were published by Huirache-Acuña et al. [43]. It was reported that the maximum activity in DBT HDS was achieved with a molar ratio of $\mathrm{Mo} /(\mathrm{Mo}+\mathrm{W})$ equal to 0.6 , which almost corresponds to the result obtained in this work. Wang et al. [44], using the density functional theory (DFT) calculations, found that the $50 \%$ substitution of Mo by W in unsupported mixed MoWS ${ }_{2}$ catalysts shows the best hydrogen activation because of the reduction of $\mathrm{H}$ adsorption free energy and facilitation of charge transfer. Further increase in the concentration of molybdenum led to a slight decrease in activity for both types of catalysts (Fig. 8). It follows 
from this case, the catalytic activity is primarily affected by the ratio of metals of the $\mathrm{Mo}(\mathrm{W}) \mathrm{S}_{2}$ active phase.

A key point is the comparison between catalytic performances of MoW catalysts synthesized from mixed $\mathrm{SiMo}_{\mathrm{n}} \mathrm{W}_{12 \text {-n } \mathrm{HPAs}}$ and from a mixture of monometallic HPA. Improved catalytic properties in both HDS and HYD reactions were noticed on $\mathrm{Mo}_{\mathrm{n}} \mathrm{W}_{12+\mathrm{n}} / \mathrm{Al}_{2} \mathrm{O}_{3}$ catalysts for all studied Mo/W ratios. These observations allowed us to conclude that the origin of the catalytic improvement is not only due to the simultaneous presence of Mo together with $\mathrm{W}$ allowing better sulfidation than that of monometallic catalysts, but also arises from the close interaction of both metals in the mixed oxide precursor. As previously described, mixed slabs are formed mainly in samples that have been synthesized from mixed HPAs [18,20]. It is confirmed here by HAADF for higher Mo/W ratios. Haandel et al. [8] also described mixed structures for Ni-Mo-W catalysts prepared from conventional precursors (AHM and AMT) and sulfided under gas phase sulfidation. It is assumed that the structure of the mixed active phase depends on the type of sulfidation: the random arrangement of metal atoms during sulfidation at high pressure and the core-shell structure during gas-phase sulfidation at low pressure [8]. Earlier, a random-structure was reported to form on a catalyst based on mixed $\mathrm{SiMo}_{3} \mathrm{~W}_{9} \mathrm{HPA}$ during liquid-phase sulfidation, while a core-shell structure is formed during gas-phase sulfidation [20]. However, from the present study, the atomic ratio in oxidic precursor can also affect the structure of mixed centers. The coreshell structure is retained for a molar $\mathrm{Mo} /(\mathrm{Mo}+\mathrm{W})$ ratio of 0.25 and 0.5 , while with ratio equal to 0.75 , a random structure prevails. For this corresponding catalyst $\mathrm{Mo}_{9} \mathrm{~W}_{3} / \mathrm{Al}_{2} \mathrm{O}_{3}$, a slight decrease in catalytic activity is observed.

For better understanding of the catalytic properties of the $\mathrm{Mo}(\mathrm{W}) \mathrm{S}_{2}$ active phase species the turnover frequencies (TOF, $\mathrm{s}^{-1}$ ) normalized on edge sites of slabs for the HDS of DBT and HYD of naphthalene were calculated using the following equations:(3) where $F_{\mathrm{DBT}}$ and $F_{\mathrm{Naph}}$ are the reactant flow $\left(\mathrm{mol} \mathrm{h}^{-1}\right) ; x_{\mathrm{DBT}}$ and $x_{\mathrm{Naph}}$ are the conversions (\%) of DBT and naphthalene, respectively; $W$ is the weight of the catalyst (g); and are the effective content of $\mathrm{W}$ and Mo, respectively, in $\mathrm{Mo}_{\mathrm{n}} \mathrm{W}_{12-\mathrm{n}} \mathrm{S}_{2}$ species (wt. \%); $D$ is the dispersion of $\mathrm{Mo}_{\mathrm{n}} \mathrm{W}_{12-\mathrm{n}} \mathrm{S}_{2}$ species; $A r_{\mathrm{W}}$ and $A r_{\mathrm{Mo}}$ are the standard atomic weight of tungsten $(183.9 \mathrm{~g} / \mathrm{mol})$ and molybdenum $(95.9 \mathrm{~g} / \mathrm{mol})$, respectively.

Fig. 10 shows the dependence of the TOF number on the Mo/(Mo + W) molar ratio for DBT HDS and naphthalene HYD. It is seen that the TOF number linearly increase with increasing molybdenum content in the mixture of $\mathrm{Mo}_{\mathrm{n}}+\mathrm{W}_{12-\mathrm{n}}$ catalysts. This dependence is fully consistent with the calculated linear dependence (triangular markers) of the additive quantities, which were calculated using the values for monometallic $\mathrm{Mo}_{12} / \mathrm{Al}_{2} \mathrm{O}_{3}$ and $\mathrm{W}_{12} / \mathrm{Al}_{2} \mathrm{O}_{3}$. The TOF number for both reactions were significantly higher for mixed $\mathrm{MoW} / \mathrm{Al}_{2} \mathrm{O}_{3}$ catalysts than for reference samples prepared from a mixture of monometallic HPAs. This difference is a strong indication of the better efficiency of mixed MoWS active sites provided by the mixed $\mathrm{MoWS}_{2}$ phase evidenced by HAADF. All mixed $\mathrm{MoW} / \mathrm{Al}_{2} \mathrm{O}_{3}$ samples have approximately similar TOF number (Fig. 10), which simply indicates a similar "mixed" nature of the active centers. A significant growth in conversion for the $\mathrm{Mo}_{6} \mathrm{~W}_{6}$ / $\mathrm{Al}_{2} \mathrm{O}_{3}$ sample can be explained by a high content of edge active sites in the crystallites (Fig. 11). It is also worth noting that an increase in the molybdenum content of more than $50 \%$ in mixed $\mathrm{Mo}_{\mathrm{n}} \mathrm{W}_{12-\mathrm{n}} / \mathrm{Al}_{2} \mathrm{O}_{3}$ catalysts does not result in an increase in catalytic activities in relation to the evolution of the number of mixed sites. This large increase of Mo is detrimental to W sulfidation and leads to a mixed $\mathrm{MoWS}_{2}$ disordered phase as shown by the HAADF images. Nevertheless, the TOF number for the reference samples is significantly inferior to the additive quantities. This could be due to the partial physical embedding of the active sites located on edges of separate $\mathrm{MoS}_{2}$ and $\mathrm{WS}_{2}$ crystallites present together at the surface of alumina.

$\mathrm{Mo}_{9} \mathrm{~W}_{3} / \mathrm{Al}_{2} \mathrm{O}_{3}$ catalyst is significantly inferior to additive TOF number and fits linearly with catalysts prepared from monometallic HPA (Fig. 10), which is consistent with the data presented by Hensen and co-workers [8]. The study of the effect of the Mo/(Mo $+\mathrm{W})$ ratio on the formation of the mixed $\mathrm{MoWS}_{2}$ phase under gas phase, as well as the determination of the effect structure of mixed $\mathrm{MoWS}_{2}$ particles on the catalytic activity allow to conclude that the random arrangement of atoms has a negative effect on catalytic activity. This conclusion is consistent with the results of the effect of the type of sulfidation on the formation of a mixed active phase [20]. Moreover, the disordered structure of the $\mathrm{Mo}_{9} \mathrm{~W}_{3} / \mathrm{Al}_{2} \mathrm{O}_{3}$ catalyst has a lower hydrogenation activity, as indicated by the HYD/DDS selectivity in DBT HDS and the reaction rate constant of the naphthalene HYD, contradicting the data of the literature [8]. However, the authors [8] did not determine the catalytic activity in the DBT HDS for catalysts with a core-shell active phase structure, which makes difficult the direct data comparison of both studies. In reference [8] one structure was tested in one reaction: the core-shell structure for the thiophene HDS reaction and the random structure for the DBT HDS reaction.

In the present study, it was shown that catalytic activity has a volcanic dependence on the Mo/(Mo + W)ratio, with a maximum at 0.5 (Fig. 12), which is consistent with published works [44]. As mentioned earlier, the active sites forming from mixed $\mathrm{Mo}_{\mathrm{n}} \mathrm{W}_{12-\mathrm{n}} \mathrm{HPAs}$ with different Mo/(Mo $+\mathrm{W})$ ratios have the same "mixed" nature (Fig. 10). Moreover, the use of mixed $\mathrm{Mo}_{\mathrm{n}} \mathrm{W}_{12-\mathrm{n}} \mathrm{HPAs}$ with an equivalent molar ratio of active metals allows the formation of a maximum number of mixed active sites on the catalyst surface. An increase of the Mo content to reach a Mo/W ratio $=9 / 3$ does not increase the number of active centers whatever the preparation method. For the mixed HPA, the slight decrease in activity is proposed to be linked to the disorder mixed sulfide structure while for the $\mathrm{Mo}_{3}+\mathrm{W}_{9}$ it may result from the co-exiting $\mathrm{MoS}_{2}$ and $\mathrm{WS}_{2}$ phase with large proportion of the Mo one likely blocking the accessibility to the $\mathrm{WS}_{2}$ crystallites edges sites.

\section{Conclusions}

A new simplified method for the synthesis of mixed Keggin's HPAs with the molar $\mathrm{Mo} /(\mathrm{Mo}+\mathrm{W})$ ratio equal to 0.5 and 0.75 through single-stage preparation has been proposed. The structure of the obtained compounds was confirmed by Raman, IR and single-XRD methods. $\mathrm{Mo}_{6} \mathrm{~W}_{6}$ and $\mathrm{Mo}_{9} \mathrm{~W}_{3}$ catalysts supported on alumina were more active in DBT HDS and naphthalene HYD reactions than their Mo + W references prepared using their monometallic counterparts, due to the formation of a mixed active phase, as observed by HAADF. It was found that the structure of active phase depends not only on the type of sulfidation which was reported previously $[8,20]$, but also on the atomic $\mathrm{Mo} /(\mathrm{Mo}+\mathrm{W})$ ratio in oxidic precursor used. An increase in this ratio from 0.25 to 0.5 allowed a significant increase in the number of edge sites more than $15 \%$ for $\mathrm{Mo}_{6} \mathrm{~W}_{6} / \mathrm{Al}_{2} \mathrm{O}_{3}$ compared to $\mathrm{Mo}_{3} \mathrm{~W}_{9}$ / $\mathrm{Al}_{2} \mathrm{O}_{3}$ and more than $30 \%$ compared to monometallic $\mathrm{Mo}_{12} / \mathrm{Al}_{2} \mathrm{O}_{3}$.

The maximum conversion of reagents in the studied reactions was achieved with a ratio of Mo to $\mathrm{W}$ equal to 1 : 1 for both types of $\mathrm{Mo}_{6} \mathrm{~W}_{6} /$ $\mathrm{Al}_{2} \mathrm{O}_{3}$ and $\mathrm{Mo}_{6}+\mathrm{W}_{6} / \mathrm{Al}_{2} \mathrm{O}_{3}$ catalysts. Mixed $\mathrm{Mo}_{6} \mathrm{~W}_{6} / \mathrm{Al}_{2} \mathrm{O}_{3}$ sample was more active than a mixture reference due to formation of highly active mixed $\mathrm{MoWS}_{2}$ slabs with core-shell structure, which was also evidenced by the HAADF images. This arrangement of atoms in the structure provides a significantly higher HYD activity, as evidenced by a higher $S_{\mathrm{HYD} / \mathrm{DDS}}$ selectivity of DBS HDS and HYD naphthalene than catalysts with a random distribution of atoms in slabs.

\section{CRediT authorship contribution statement}

A. Kokliukhin: Investigation, Writing - original draft. M. Nikulshina: Validation, Writing - original draft. A. Mozhaev: Investigation. C. Lancelot: Investigation, Writing - review \& editing. P. Blanchard: Investigation, Validation. O. Mentré: Investigation. M. Marinova: Investigation. C. Lamonier: Conceptualization, Writing review \& editing. P. Nikulshin: Conceptualization, Writing - review \& editing. 


\section{Declaration of Competing Interest}

The authors declare that they have no known competing financial interests or personal relationships that could have appeared to influence the work reported in this paper.

\section{Acknowledgments}

The authors thank Russian Science Foundation for financial support of theoretical part of the investigation by Grant No. 17-73-20386. The preparation and testing parts have been supported by the Government of Russian Federation (decree №220 of April 9, 2010), agreement №14.Z50.31.0038. The research was financially supported by the Ministry of Foreign Affairs and International Development (France), the Ministry of National Education, Higher Education and Research (France) in the framework of PHC Kolmogorov PHC 2017-2019. The TEM facility in Lille (France) is supported by the Conseil Regional du Nord-Pas de Calais and the European Regional Development Fund (ERDF). The authors thank the Chevreul Institute (FR 2638) for its help in the development of this work. Chevreul Institute is supported by the "Ministère de l'Enseignement Supérieur et de la Recherche», the «Région Nord-Pas de calais» and the «Fonds Européen de Développement des Régions».

\section{References}

[1] F. Lin, Y. Zhang, L. Wang, Y. Zhang, D. Wang, M. Yang, J. Yang, B. Zhang, Z. Jiang, C. Li, Appl. Catal. B 127 (2012) 363-370.

[2] D. Valencia, T. Klimova, Appl. Catal. B 129 (2013) 137-145.

[3] International Energy Outlook 2019 With Projections to 2050, (2019) . https:// www.eia.gov/outlooks/ieo/.

[4] C. Perego, A. Bosetti, Micropor. Mesopor. Mat. 144 (2011) 28-39.

[5] H. Lü, W. Ren, W. Liao, W. Chen, Y. Li, Z. Suo, Appl. Catal. B 138-139 (2013) 79-83.

[6] C. Thomazeau, C. Geantet, M. Lacroix, M. Danot, V. Harle, P. Raybaud, Appl. Catal. A Gen. 322 (2007) 92-97.

[7] P.J. Vázquez-Salas, R. Huirache-Acuña, T.A. Zepeda, G. Alonso-Núñez, R. MayaYescas, N. Mota, B. Pawelec, Catal. Today 305 (2018) 65-74.

[8] L. van Haandel, M. Bremmer, P.J. Kooyman, J.A. Rob van Veen, T. Weber, E.J.M. Hensen, ACS Catal. 5 (2015) 7276-7287.

[9] S. Sigurdson, V. Sundaramurthy, A.K. Dalai, J. Adjaye, J. Mol. Catal. A-Chem. 291 (2008) 30-37.

[10] G. An, C. Liu, C. Xiong, C. Lu, Petrol. Sci. Technol. 30 (2012) 1599-1608.

[11] J.A. Mendoza-Nieto, O. Vera-Vallejo, L. Escobar-Alarcón, D. Solís-Casados, T. Klimova, Fuel 110 (2013) 268-277.

[12] R. Huirache-Acuña, B. Pawelec, C.V. Loricera, E.M. Rivera-Mũnoz, R. Nava, B. Torres, J.L.G. Fierro, Appl. Catal. B 125 (2012) 473-485.
[13] P. Nikulshin, A. Mozhaev, C. Lancelot, P. Blanchard, E. Payen, C. Lamonier, C.R Chim. 19 (2016) 1276-1285.

[14] R. Shafi, M.R.H. Siddiqui, G.J. Hutchings, E.G. Derouane, I.V. Kozhevnikov, Appl. Catal. 204 (2000) 251-256.

[15] P. Blanchard, C. Lamonier, A. Griboval, E. Payen, Appl. Catal. A Gen. 322 (2007) 33-45.

[16] C.I. Cabello, F.M. Cabrerizo, A. Alvarez, H.J. Thomas, J. Mol. Catal. A-Chem. 186 (2002) 89-100.

[17] C. Lamonier, C. Martin, J. Mazurelle, V. Harlé, D. Guillaume, E. Payen, Appl. Catal. B 70 (2007) 548-556.

[18] M. Nikulshina, A. Mozhaev, C. Lancelot, M. Marinova, P. Blanchard, E. Payen, C. Lamonier, P. Nikulshin, Appl. Catal. B 224 (2018) 951-959.

[19] M. Nikulshina, P. Blanchard, A. Mozhaev, C. Lancelot, A. Griboval-Constant, M. Fournier, C. Lamonier, Catal. Sci. Technol. 8 (2018) 5557-5572.

[20] M. Nikulshina, A. Mozhaev, C. Lancelot, P. Blanchard, M. Marinova, C. Lamonier, P. Nikulshin, Catal. Today 329 (2019) 24-34.

[21] M.T. Pope, Heteropoly and Isopoly Oxometalates, Springer-Verlag, Berlin, 1983.

[22] SAINT: Area-Detector Integration Software, Madison: Siemens Industrial Automation, Inc., 1996.

[23] G. Sheldrix, SADABS: Area Detector Absorption Correction, Madison, WI, 1996.

[24] L. Palatinus, G. Chapuis, J. Appl. Crystallogr. 40 (2007) 786-790.

[25] V. Petricek, M. Dusek, L. Palatinus, Kristallografiya 229 (2014) 345-352.

[26] S. Kasztelan, H. Toulhoat, J. Grimblot, J.P. Bonnelle, Appl. Catal. 13 (1984) 127-159.

[27] A.V. Mozhaev, P.A. Nikulshin, Al.A. Pimerzin, K.I. Maslakov, A.A. Pimerzin, Catal. Today 271 (2016) 80-90.

[28] A. Cordova, P. Blanchard, C. Lancelot, G. Frémy, C. Lamonier, ACS Catal. 5 (2015) 2966-2981.

[29] C. Rocchiccioli-Deltcheff, M. Fournier, R. Franck, R. Thouvenot, Inorg. Chem. 22 (1983) 207-216.

[30] C. Rocchiccioli-Deltcheff, R. Thouvenot, R. Franck, Spectrochim. Acta A. 32 (1976) $587-597$.

[31] A.J. Bridgeman, Chem. Phys. 287 (2003) 55-69.

[32] A.J. Bridgeman, Chem. Eur. J. 10 (2004) 2935-2941.

[33] L.C. Teague, D. Chen, J.J. Boland, J. Phys. Chem. B 108 (2004) 7827-7830.

[34] M. Muñoz, C.I. Cabello, I.L. Botto, G. Minelli, M. Capron, C. Lamonier, E. Payen, J. Mol. Struct. 841 (2007) 96-103.

[35] L. Catita, A.-A. Quoineaud, D. Espinat, C. Pichon, O. Delpoux, Appl. Catal. A Gen. 547 (2017) 164-175.

[36] L. Le Bihan, P. Blanchard, M. Fournier, J. Grimblot, E. Payen, J. Chem. Soc. Faraday Trans. 94 (1998) 937-940.

[37] X. Carrier, J.F. Lambert, M. Che, J. Am. Chem. Soc. 119 (1997) 10137-10146.

[38] P. Hartel, H. Rose, C. Dignes, Ultramicroscopy 63 (1996) 93-114.

[39] M. Nikulshina, P. Blanchard, C. Lancelot, A. Griboval-Constant, M. Marinova, V. Briois, P. Nikulshin, C. Lamonier, Appl. Catal. B 269 (2020) 118766.

[40] R. Thomas, E.M. van Oers, V.H.J. de Beer, J. Medema, J.A. Moulijn, J. Catal. 76 (1982) 241-253.

[41] T.F. Hayden, J.A. Dumesic, R.D. Sherwood, R.T.K. Baker, J. Catal. 105 (1987) 299-318.

[42] E. Payen, R. Hubaut, S. Kasztelan, O. Poulet, J. Grimblot, J. Catal. 147 (1994) $123-132$

[43] R. Huirache-Acuña, B. Pawelec, E.M. Rivera-Muñoz, R. Guil-López, J.L.G. Fierro, Fuel 198 (2017) 145-158.

[44] H. Wang, L. Ouyang, G. Zou, C. Sun, J. Hu, X. Xiao, L. Gao, ACS Catal. (2018) 1-22. 